4

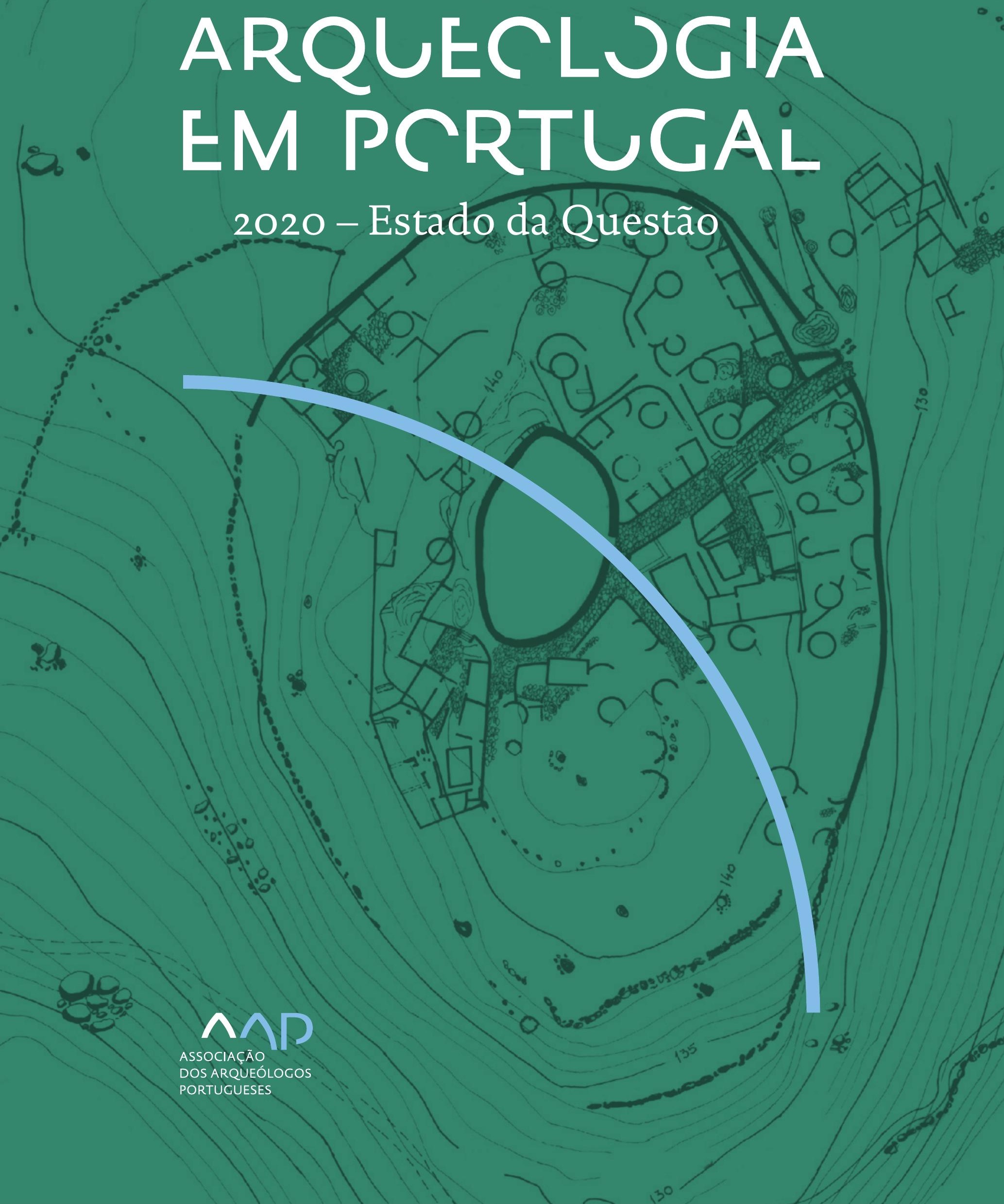


Coordenação editorial: José Morais Arnaud, César Neves e Andrea Martins Design gráfico: Flatland Design

AAP - ISBN: 978-972-9451-89-8

CITCEM - ISBN: 978-989-8970-25-1

Associação dos Arqueólogos Portugueses e CITCEM

Lisboa, 2020

O conteúdo dos artigos é da inteira responsabilidade dos autores. Sendo assim a Associação dos Arqueólogos Portugueses declina qualquer responsabilidade por eventuais equívocos ou questões de ordem ética e legal.

Desenho de capa:

Planta do castro de Monte Mozinho (Museu Municipal de Penafiel).

\section{$\hat{\wedge} \mathrm{P}$}

DOS ARQUEÓLOGOS PORTUGUESES

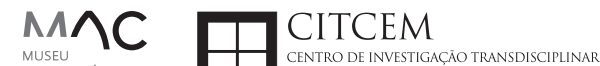
MUSEU
ARQUELLÓGICO
DO CARMO
U.PORTO

FLUP FACULDADE DE LETRAS
UNIVERSIDADE DO PORTO

Apoio

EC para a Ciência 


\section{Índice}

15 Prefácio

José Morais Arnaud

\section{Historiografia e Teoria}

17 Território, comunidade, memória e emoção: a contribuição da história da arqueologia (algumas primeiras e breves reflexões)

Ana Cristina Martins

25 Como descolonizar a arqueologia portuguesa?

Rui Gomes Coelho

41 Arqueologia e Modernidade: uma revisitação pessoal e breve de alguns aspetos da obra homónima de Julian Thomas de 2004

Vítor Oliveira Jorge

57 Dados para a História das Mulheres na Arqueologia portuguesa, dos finais do século XIX aos inícios do século XX: números, nomes e tabelas

Filipa Dimas / Mariana Diniz

73 Retractos da arqueologia portuguesa na imprensa: (in)visibilidades no feminino

Catarina Costeira / Elsa Luís

85 Arqueologia e Arqueólogos no Norte de Portugal Jacinta Bugalhão

101 Vieira Guimarães (1864-1939) e a arqueologia em Tomar: uma abordagem sobre o território e as gentes

João Amendoeira Peixoto / Ana Cristina Martins

115 Os memoráveis? A arqueologia algarvia na imprensa nacional e regional na presente centúria (2001-2019): características, visões do(s) passado(s) e a arqueologia

enquanto marca

Frederico Agosto / João Silva

129 A Evolução da Arqueologia Urbana e a Valorização Patrimonial no Barlavento Algarvio: Os casos de Portimão e Silves

Artur Mateus / Diogo Varandas / Rafael Boavida

\section{Gestão, Valorização e Salvaguarda do Património}

145 O Caderno Reivindicativo e as condições de trabalho em Arqueologia Miguel Rocha / Liliana Matias Carvalho / Regis Barbosa / Mauro Correia / Sara Simões / Jacinta Bugalhão / Sara Brito / Liliana Veríssimo Carvalho / Richard Peace / Pedro Peça / Cézer Santos

155 Os Estudos de Impacte Patrimonial como elemento para uma estratégia sustentável de minimização de impactes no âmbito de reconversões agrícolas Tiago do Pereiro

165 Salvaguarda de Património arqueológico em operações florestais: gestão e sensibilização Filipa Bragança / Gertrudes Zambujo / Sandra Lourenço / Belém Paiva / Carlos Banha / Frederico Tatá Regala / Helena Moura / Jacinta Bugalhão / João Marques / José Correia / Pedro Faria / Samuel Melro

179 Os valores do Património: uma investigação sobre os Sítios Pré-históricos de Arte Rupestre do Vale do Rio Côa e de Siega Verde José Paulo Francisco 
189 Conjugando recursos arqueológicos e naturais para potenciar as visitas ao Geoparque Litoral de Viana do Castelo (Noroeste de Portugal)

Hugo A. Sampaio / Ana M.S. Bettencourt / Susana Marinho / Ricardo Carvalhido

203 Áreas de Potencial Arqueológico na Região do Médio Tejo: Modelo Espacial Preditivo Rita Ferreira Anastácio / Ana Filipa Martins / Luiz Oosterbeek

223 Património Arqueológico e Gestão Territorial: O contributo da Arqueologia para a revisão do PDM de Avis

Ana Cristina Ribeiro

237 A coleção arqueológica do extinto Museu Municipal do Porto - Origens, Percursos e Estudos

Sónia Couto

251 Valpaços - uma nova carta arqueológica

Pedro Pereira / Maria de Fátima Casares Machado

263 Arqueologia na Cidade de Peniche

Adriano Constantino / Luís Rendeiro

273 Arqueologia Urbana: a cidade de Lagos como caso de Estudo Cátia Neto

285 Estratégias de promoção do património cultural subaquático nos Açores. O caso da ilha do Faial

José Luís Neto / José Bettencourt / Luís Borges / Pedro Parreira

297 Carta Arqueológica da Cidade Velha: Uma primeira abordagem

Jaylson Monteiro / Nireide Tavares / Sara da Veiga / Claudino Ramos / Edson Brito /

Carlos Carvalho / Francisco Moreira / Adalberto Tavares

311 Antropologia Virtual: novas metodologias para a análise morfológica e funcional Ricardo Miguel Godinho / Célia Gonçalves

\section{Didáctica da Arqueologia}

327 Como os projetos de Arqueologia podem contribuir para uma comunidade culturalmente mais consciente Alexandra Figueiredo / Claúdio Monteiro / Adolfo Silveira / Ricardo Lopes

337 Educação Patrimonial - Um cidadão esclarecido é um cidadão ativo! Ana Paula Almeida

351 A aproximação da Arqueologia à sala de aula: um caso de estudo no $3^{\circ}$ ciclo do Ensino Básico Luís Serrão Gil

363 Arqueologia 3.o - Pensar e comunicar a Arqueologia para um futuro sustentável Mónica Rolo

377 “Conversa de Arqueólogos" - Divulgar a Arqueologia em tempos de Pandemia Diogo Teixeira Dias

389 Escola Profissional de Arqueologia: desafios e oportunidades Susana Nunes / Dulcineia Pinto / Júlia Silva / Ana Mascarenhas

399 Os Museus de Arqueologia e os Jovens: a oferta educativa para o público adolescente Beatriz Correia Barata / Leonor Medeiros

411 O museu universitário como mediador entre a ciência e a sociedade: o exemplo da secção de arqueologia no Museu de História Natural e da Ciência da Universidade do Porto (MHNC-UP)

Rita Gaspar 
421 Museu de Lanifícios: Real Fábrica de Panos. Atividades no âmbito da Arqueologia Beatriz Correia Barata / Rita Salvado

427 Arqueologia Pública e o caso da localidade da Mata (Torres Novas) Cláudia Manso / Ana Rita Ferreira / Cristiana Ferreira / Vanessa Cardoso Antunes

431 Do sítio arqueológico ao museu: um percurso (também) didático Lídia Fernandes

447 Estão todos convidados para a Festa! E para dançar também... O projecto do Serviço Educativo do Museu Arqueológico do Carmo na $5^{\underline{a}}$ Edição da Festa da Arqueologia Rita Pires dos Santos

459 O “Clã de Carenque”, um projeto didático de arqueologia Eduardo Gonzalez Rocha

469 Mediação cultural: peixe que puxa carroça nas Ruínas Romanas de Troia Inês Vaz Pinto / Ana Patrícia Magalhães / Patrícia Brum / Filipa Santos

481 Didática Arqueológica, experiências do Projeto Mértola Vila Museu Maria de Fátima Palma / Clara Rodrigues / Susana Gómez / Lígia Rafael

\section{Arte Rupestre}

497 Os inventários de arte rupestre em Portugal Mila Simões de Abreu

513 O projeto FIRST-ART - conservação, documentação e gestão das primeiras manifestações de arte rupestre no Sudoeste da Península Ibérica: as grutas do Escoural e Maltravieso Sara Garcês / Hipólito Collado / José Julio García Arranz / Luiz Oosterbeek / António Carlos Silva / Pierluigi Rosina / Hugo Gomes / Anabela Borralheiro Pereira / George Nash / Esmeralda Gomes / Nelson Almeida / Carlos Carpetudo

523 Trabalhos de documentação de arte paleolítica realizados no âmbito do projeto PalæoCôa André Tomás Santos / António Fernando Barbosa / Luís Luís / Marcelo Silvestre / Thierry Aubry

537 Imagens fantasmagóricas, silhuetas elusivas: as figuras humanas na arte do Paleolítico Superior da região do Côa Mário Reis

$55^{1}$ Os motivos zoomórficos representados nas placas de tear de Vila Nova de São Pedro (Azambuja, Portugal) Andrea Martins / César Neves / José M. Arnaud / Mariana Diniz

571 Arte Rupestre do Monte de Góios (Lanhelas, Caminha). Síntese dos resultados dos trabalhos efectuados em 2007-2009 Mário Varela Gomes

599 Gravuras rupestres de barquiformes no Monte de S. Romão, Guimarães, Noroeste de Portugal Daniela Cardoso

613 Círculos segmentados gravados na Bacia do Rio Lima (Noroeste de Portugal): contributos para o seu estudo Diogo Marinho / Ana M.S. Bettencourt / Hugo Aluai Sampaio

631 Equídeos gravados no curso inferior do Rio Mouro, Monção (NW Portugal). Análise preliminar Coutinho, L.M. / Bettencourt, A.M.S / Sampaio, Hugo A.S

645 Paletas na Arte Rupestre do Noroeste de Portugal. Inventário preliminar Bruna Sousa Afonso / Ana M. S. Bettencourt / Hugo A. Sampaio 


\section{Pré-História}

661 O projeto Miño/Minho: balanço de quatro anos de trabalhos arqueológicos Sérgio Monteiro-Rodrigues / João Pedro Cunha-Ribeiro / Eduardo Méndez-Quintas / Carlos Ferreira / Pedro Xavier / José Meireles / Alberto Gomes / Manuel Santonja / Alfredo Pérez-González

677 A ocupação paleolítica da margem esquerda do Baixo Minho: a indústria lítica do sítio de Pedreiras 2 (Monção, Portugal) e a sua integração no contexto regional Carlos Ferreira / João Pedro Cunha-Ribeiro / Sérgio Monteiro-Rodrigues / Eduardo Méndez-Quintas / Pedro Xavier / José Meireles / Alberto Gomes / Manuel Santonja / Alfredo Pérez-González

693 O sítio acheulense do Plistocénico médio da Gruta da Aroeira Joan Daura / Montserrat Sanz / Filipa Rodrigues / Pedro Souto / João Zilhão

703 As sociedades neandertais no Barlavento algarvio: modelos preditivos com recurso aos SIG

Daniela Maio

715 A utilização de quartzo durante o Paleolítico Superior no território dos vales dos rios Vouga e Côa

Cristina Gameiro / Thierry Aubry / Bárbara Costa / Sérgio Gomes / Luís Luís / Carmen Manzano / André Tomás Santos

733 Uma perspetiva diacrónica da ocupação do concheiro do Cabeço da Amoreira (Muge, Portugal) a partir da tecnologia lítica Joana Belmiro / João Cascalheira / Célia Gonçalves

745 Novos dados sobre a Pré-história Antiga no concelho de Palmela. A intervenção arqueológica no sítio do Poceirão I

Michelle Teixeira Santos

757 Problemas em torno de Datas Absolutas Pré-Históricas no Norte do Alentejo Jorge de Oliveira

771 Povoamento pré-histórico nas áreas montanhosas do NO de Portugal: o Abrigo 1 de Vale de Cerdeira Pedro Xavier / José Meireles / Carlos Alves

783 Apreciação do povoamento do Neolítico Inicial na Baixa Bacia do Douro. A Lavra I (Serra da Aboboreira) como caso de estudo Maria de Jesus Sanches

797 O Processo de Neolitização na Plataforma do Mondego: os dados do Sector C do Outeiro dos Castelos de Beijós (Carregal do Sal)

João Carlos de Senna-Martinez / José Manuel Quintã Ventura / Andreia Carvalho / Cíntia Maurício

823 Novos trabalhos na Lapa da Bugalheira (Almonda, Torres Novas) Filipa Rodrigues / Pedro Souto / Artur Ferreira / Alexandre Varanda / Luís Gomes / Helena Gomes / João Zilhão

837 A pedra polida e afeiçoada do sítio do Neolítico médio da Moita do Ourives (Benavente, Portugal)

César Neves

857 Casal do Outeiro (Encarnação, Mafra): novos contributos para o conhecimento do povoamento do Neolítico final na Península de Lisboa.

Cátia Delicado / Carlos Maneira e Costa / Marta Miranda / Ana Catarina Sousa

873 Stresse infantil, morbilidade e mortalidade no sítio arqueológico do Neolítico Final/ Calcolítico ( $4^{\circ}$ e $3^{\circ}$ milénio a.C.) do Monte do Carrascal 2 (Ferreira do Alentejo, Beja) Liliana Matias de Carvalho / Sofia N. Wasterlain 
885 Come together: O Conjunto Megalítico das Motas (Monção, Viana do Castelo) e as expressões Campaniformes do Alto Minho Ana Catarina Basílio / Rui Ramos

899 Trabalhos arqueológicos no sítio Calcolítico da Pedreira do Poio Carla Magalhães / João Muralha / Mário Reis / António Batarda Fernandes

913 O sítio arqueológico de Castanheiro do Vento. Da arquitectura do sítio à arquitectura de um território João Muralha Cardoso

925 Estudo zooarqueológico das faunas do Calcolítico final de Vila Nova de São Pedro (Azambuja, Portugal): Campanhas de 2017 e 2018 Cleia Detry / Ana Catarina Francisco / Mariana Diniz / Andrea Martins / César Neves / José Morais Arnaud

943 As faunas depositadas no Museu Arqueológico do Carmo provenientes de Vila Nova de São Pedro (Azambuja): as campanhas de 1937 a 1967 Ana Catarina Francisco / Cleia Detry / César Neves / Andrea Martins / Mariana Diniz / José Morais Arnaud

959 Análise funcional de material lítico em sílex do castro de Vila Nova de S. Pedro (Azambuja, Portugal): uma primeira abordagem Rafael Lima

971 O recinto da Folha do Ouro 1 (Serpa) no contexto dos recintos de fossos calcolíticos alentejanos

António Carlos Valera / Tiago do Pereiro / Pedro Valério / António M. Monge Soares

\section{Proto-História}

987 Produção de sal marinho na Idade do Bronze do noroeste Português. Alguns dados para uma reflexão

Ana M. S. Bettencourt / Sara Luz / Nuno Oliveira / Pedro P. Simões / Maria Isabel C. Alves / Emílio Abad-Vidal

1001 A estátua-menir do Pedrão ou de São Bartolomeu do Mar (Esposende, noroeste de Portugal) no contexto arqueológico da fachada costeira de entre os rios Neiva e Cávado Ana M. S. Bettencourt / Manuel Santos-Estévez / Pedro Pimenta Simões / Luís Gonçalves

1015 O Castro do Muro (Vandoma/Baltar, Paredes) - notas para uma biografia de ocupação da Idade do Bronze à Idade Média

Maria Antónia D. Silva / Ana M. S. Bettencourt / António Manuel S. P. Silva / Natália Félix

1031 Do Bronze Final à Idade Média - continuidades e hiatos na ocupação de Povoados em Oliveira de Azeméis João Tiago Tavares / Adriaan de Man

1041 As faunas do final da Idade do Bronze no Sul de Portugal: leituras desde o Outeiro do Circo (Beja)

Nelson J. Almeida / Íris Dias / Cleia Detry / Eduardo Porfírio / Miguel Serra

1055 A Espada do Monte das Oliveiras (Serpa) - uma arma do Bronze Pleno do Sudoeste Rui M. G. Monge Soares / Pedro Valério / Mariana Nabais / António M. Monge Soares

1065 São Julião da Branca (Albergaria-a-Velha) - Investigação e valorização de um povoado do Bronze Final

António Manuel S. P. Silva / Paulo A. P. Lemos / Sara Almeida e Silva / Edite Martins de Sá

1083 Do castro de S. João ao Mosteiro de Santa Clara: notícia de uma intervenção arqueológica, em Vila do Conde Rui Pinheiro 
1095 O castro de Ovil (Espinho), um quarto de século de investigação - resultados e questões em aberto

Jorge Fernando Salvador / António Manuel S. P. Silva

1111 O Castro de Salreu (Estarreja), um povoado proto-histórico no litoral do Entre Douro e Vouga

Sara Almeida e Silva / António Manuel S. P. Silva / Paulo A. P. Lemos / Edite Martins de Sá

1127 Castro de Nossa Senhora das Necessidades (Sernancelhe): uma primeira análise artefactual Telma Susana O. Ribeiro

${ }_{1141}$ A cividade de Bagunte. O estado atual da investigação Pedro Brochado de Almeida

1153 Zoomorfos na cerâmica da Idade do Ferro no NW Peninsular: inventário, cronologias e significado Nuno Oliveira / Cristina Seoane

1163 Vasos gregos em Portugal: diferentes maneiras de contar a história do intercâmbio cultural na Idade do Ferro

Daniela Ferreira

1175 Os exotica da necrópole da Idade do Ferro do Olival do Senhor dos Mártires (Alcácer do Sal) no seu contexto regional

Francisco B. Gomes

\section{Antiguidade Clássica e Tardia}

1191 O uso de madeira como combustível no sítio da Quinta de Crestelos (Baixo Sabor): da Idade do Ferro à Romanização Filipe Vaz / João Tereso / Sérgio Simões Pereira / José Sastre / Javier Larrazabal Galarza / Susana Cosme / José António Pereira / Israel Espi

1207 Cultivos de Época Romana no Baixo Sabor: continuidade em tempos de mudança? João Pedro Tereso / Sérgio Simões Pereira / Filipe Santos / Luís Seabra / Filipe Vaz

1221 A casa romana na Hispânia: aplicação dos modelos itálicos nas províncias ibéricas Fernanda Magalhães / Diego Machado / Manuela Martins

1235 As pinturas murais romanas da Rua General Sousa Machado, n. ${ }^{5}$ 1, Chaves José Carvalho

1243 Trás do Castelo (Vale de Mir, Pegarinhos, Alijó) - Uma exploração agrícola romana do Douro

Tony Silvino / Pedro Pereira

1255 A sequência de ocupação no quadrante sudeste de Bracara Augusta: as transformações de uma unidade doméstica Lara Fernandes / Manuela Martins

1263 Os Mosaicos com decoração geométrica e geométrico-vegetalista dos sítios arqueológicos da área do Conuentus Bracaraugustanus. Novas abordagens quanto à conservação, restauro, decoração e datação Maria de Fátima Abraços / Licínia Wrench

1277 “Casa Romana” do Castro de São Domingos (Cristelos, Lousada): Escavação, Estudo e Musealização Paulo André de P. Lemos

1291 A arqueobotânica no Castro de Guifões (Matosinhos, Noroeste de Portugal): O primeiro estudo carpológico

Luís Seabra / Andreia Arezes / Catarina Magalhães / José Varela / João Pedro Tereso 
1305 Um Horreum Augustano na Foz do Douro (Monte do Castelo de Gaia, Vila Nova de Gaia) Rui Ramos

1311 Ponderais romanos na Lusitânia: padrões, formas, materiais e contextos de utilização Diego Barrios Rodríguez

1323 Um almofariz centro-itálico na foz do Mondego

Marco Penajoia

1335 Estruturas romanas de Carnide - Lisboa Luísa Batalha / Mário Monteiro / Guilherme Cardoso

1347 O contexto funerário do sector da "necrópole NO" da Rua das Portas de S. Antão (Lisboa): o espaço, os artefactos, os indivíduos e a sua interconectividade na interpretação do passado Sílvia Loja, José Carlos Quaresma, Nelson Cabaço, Marina Lourenço, Sílvia Casimiro, Rodrigo Banha da Silva, Francisca Alves-Cardoso

${ }_{1361}$ Povoamento em época Romana na Amadora - resultados de um projeto pluridisciplinar Gisela Encarnação / Vanessa Dias

1371 A Arquitectura Residencial em Mirobriga (Santiago do Cacém): contributo a partir de um estudo de caso Filipe Sousa / Catarina Felício

${ }_{1385}$ O fim do ciclo. Saneamento e gestão de resíduos nos edifícios termais de Mirobriga (Santiago do Cacém)

Catarina Felício / Filipe Sousa

1399 Balsa, Topografia e Urbanismo de uma Cidade Portuária Vítor Silva Dias / João Pedro Bernardes / Celso Candeias / Cristina Tété Garcia

1413 No Largo das Mouras Velhas em Faro (2017): novas evidências da necrópole norte de Ossonoba e da sua ocupação medieval Ricardo Costeira da Silva / Paulo Botelho / Fernando Santos / Liliana Nunes

1429 Instrumentos de pesca recuperados numa fábrica de salga em Ossonoba (Faro) Inês Rasteiro / Ricardo Costeira da Silva / Paulo Botelho

1439 A Necrópole Romana do Eirô, Duas Igrejas (Penafiel): intervenção arqueológica de 2016 Laura Sousa / Teresa Soeiro

1457 Ritual, descarte ou afetividade? A presença de Canis lupus familiaris na Necrópole Noroeste de Olisipo (Lisboa)

Beatriz Calapez Santos / Sofia Simões Pereira / Rodrigo Banha da Silva / Sílvia Casimiro / Cleia Detry / Francisca Alves Cardoso

1467 Dinâmicas económicas em Bracara na Antiguidade Tardia Diego Machado / Manuela Martins / Fernanda Magalhães / Natália Botica

1479 Cerâmicas e Vidros da Antiguidade Tardia do Edifício sob a Igreja do Bom Jesus (Vila Nova de Gaia) Joaquim Filipe Ramos

1493 Novos contributos para a topografia histórica de Mértola no período romano e na Antiguidade Tardia Virgílio Lopes

\section{8. Época Medieval}

1511 Cerâmicas islâmicas no Garb setentrional "português": algumas evidências e incógnitas Constança dos Santos / Helena Catarino / Susana Gómez / Maria José Gonçalves / Isabel Inácio / Gonçalo Lopes / Jacinta Bugalhão / Sandra Cavaco / Jaquelina Covaneiro / Isabel Cristina Fernandes / Ana Sofia Gomes 
1525 Contributo para o conhecimento da cosmética islâmica, em Silves, durante a Idade Média Rosa Varela Gomes

1537 Yábura e o seu território - uma análise histórico-arqueológica de Évora entre os séculos VIII-XII José Rui Santos

1547 A encosta sul do Castelo de Palmela - resultados preliminares da escavação arqueológica Luís Filipe Pereira / Michelle Teixeira Santos

1559 A igreja de São Lourenço (Mouraria, Lisboa): um conjunto de silos e de cerâmica medieval islâmica

Andreia Filipa Moreira Rodrigues

1571 O registo material de movimentações populacionais no Médio Tejo, durante os séculos XII-XIII. Dois casos de "sunken featured buildings", nos concelhos de Cartaxo e Torres Novas Marco Liberato / Helena Santos / Nuno Santos

1585 O nordeste transmontano nos alvores da Idade média. Notas para reflexão Ana Maria da Costa Oliveira

1601 Sepulturas escavadas na rocha do Norte de Portugal e do Vale do Douro: primeiros resultados do Projecto SER-NPVD

Mário Jorge Barroca / César Guedes / Andreia Arezes / Ana Maria Oliveira

1619 "Portucalem Castrum Novum" entre o Mediterrâneo e o Atlântico: o estudo dos materiais cerâmicos alto-medievais do arqueossítio da rua de D. Hugo, nํ. 5 (Porto) João Luís Veloso

1627 A Alta Idade Média na fronteira de Lafões: notas preliminares sobre a Arqueologia no Concelho de Vouzela

Manuel Luís Real / Catarina Tente

1641 Um conjunto cerâmico medieval fora de portas: um breve testemunho aveirense Susana Temudo

${ }_{1651}$ Os Lóios do Porto: uma perspetiva integrada no panorama funerário da Baixa Idade Média à Época Moderna em meios urbanos em Portugal

Ana Lema Seabra

1659 O Caminho Português Interior de Santiago como eixo viário na Idade Média Pedro Azevedo

1665 Morfologia Urbana: Um exercício em torno do Castelo de Ourém André Donas-Botto / Jaqueline Pereira

1677 Intervenção arqueológica na Rua Marquês de Pombal/Largo do Espírito Santo (Bucelas, Loures)

Florbela Estêvão / Nathalie Antunes-Ferreira / Dário Ramos Neves / Inês Lisboa

1691 O Cemitério Medieval do Poço do Borratém e a espacialidade funerária na cidade de Lisboa Inês Belém / Vanessa Filipe / Vasco Noronha Vieira / Sónia Ferro / Rodrigo Banha da Silva

1705 Um Espaço Funerário Conventual do séc. XV em Lisboa: o caso do Convento de São Domingos da Cidade Sérgio Pedroso / Sílvia Casimiro / Rodrigo Banha da Silva / Francisca Alves Cardoso

\section{9. Época Moderna e Contemporânea}

1721 Arqueologia Moderna em Portugal: algumas reflexões críticas em torno da quantificação de conjuntos cerâmicos e suas inferências históricas e antropológicas Rodrigo Banha da Silva / André Bargão / Sara da Cruz Ferreira

1733 Faianças de dois contextos entre os finais do século XVI e XVIII do Palácio dos Condes de Penafiel, Lisboa

Martim Lopes / Tomás Mesquita 
1747 Um perfil de consumo do século XVIII na foz do Tejo: O caso do Mercado da Ribeira, Lisboa Sara da Cruz Ferreira / Rodrigo Banha da Silva / André Bargão

1761 Os Cachimbos dos Séculos XVII e XVIII do Palácio Mesquitela e Convento dos Inglesinhos (Lisboa)

Inês Simão / Marina Pinto / João Pimenta / Sara da Cruz Ferreira / André Bargão / Rodrigo Banha da Silva

1775 "Tomar os fumos da erua que chamão em Portugal erua sancta». Estudo de Cachimbos provenientes da Rua do Terreiro do Trigo, Lisboa

Miguel Martins de Sousa / José Pedro Henriques / Vanessa Galiza Filipe

1787 Cachimbos de Barro Caulínitico da Sé da Cidade Velha (República de Cabo Verde)

Rodrigo Banha da Silva / João Pimenta / Clementino Amaro

1801 Algumas considerações sobre espólio não cerâmico recuperado no Largo de Jesus (Lisboa) Carlos Boavida

1815 Adereços de vidro, dos séculos XVI-XVIII, procedentes do antigo Convento de Santana de Lisboa (anéis, braceletes e contas)

Joana Gonçalves / Rosa Varela Gomes / Mário Varela Gomes

1837 Da ostentação, luxo e poder à simplicidade do uso quotidiano: arqueologia e simbologia de joias e adornos da Idade Moderna Portuguesa Jéssica Iglésias

1849 Os amuletos em Portugal - dos objetos às superstições: o coral vermelho Alexandra Vieira

1865 Cerâmicas de Vila Franca de Xira nos séculos XV e XVI Eva Pires

1879 «Não passa por teu o que me pertence». Marcas de individualização associadas a faianças do Convento de Nossa Senhora de Aracoeli, Alcácer do Sal Catarina Parreira / Íris Fragoso / Miguel Martins de Sousa

1891 Cerâmica de Leiria: alguns focos de produção

Jaqueline Pereira / André Donas-Botto

1901 Os Fornos na Rua da Biquinha, em Óbidos Hugo Silva / Filipe Oliveira

1909 A casa de Pêro Fernandes, contador dos contos de D. Manuel I: o sítio arqueológico da Silha do Alferes, Seixal (século XVI) Mariana Nunes Ferreira

1921 O Alto da Vigia (Sintra) e a vigilância e defesa da costa Alexandre Gonçalves / Sandra Santos

1937 O contexto da torre sineira da Igreja de Santa Maria de Loures Paulo Calaveira / Martim Lopes

1949 A Necrópole do Hospital Militar do Castelo de São Jorge e as práticas funerárias na Lisboa de Época Moderna Susana Henriques / Liliana Matias de Carvalho / Ana Amarante / Sofia N. Wasterlain

1963 SAND - Sarilhos Grandes Entre dois Mundos: o adro da Igreja e a Paleobiologia dos ossos humanos recuperados

Paula Alves Pereira / Roger Lee Jesus / Bruno M. Magalhães

1975 Expansão urbana da vila de Cascais no século XVII e XVIII: a intervenção arqueológica na Rua da Vitória no 15 a 17

Tiago Pereira / Vanessa Filipe

1987 Novos dados para o conhecimento do Urbanismo de Faro em época Moderna Ana Rosa 
1995 Um exemplo de Arqueologia Urbana em Alcoutim: o Antigo Edifício dos CTT Marco Fernandes / Marta Dias / Alexandra Gradim / Virgílio Lopes / Susana Gómez Martínez

2007 Palácio dos Ferrazes (Rua das Flores/Rua da Vitória, Porto): a cocheira de Domingos Oliveira Maia

Francisco Raimundo

2021 As muitas vidas de um edifício urbano: História, Arqueologia e Antropologia no antigo Recreatório Paroquial de Penafiel Helena Bernardo / Jorge Sampaio / Marta Borges

2035 O convento de Nossa Senhora da Esperança de Ponta Delgada: o contributo da arqueologia para o conhecimento de um monumento identitário João Gonçalves Araújo / N’Zinga Oliveira

2047 Arqueologia na ilha do Corvo... em busca da capela de Nossa Senhora do Rosário Tânia Manuel Casimiro / José Luís Neto / Luís Borges / Pedro Parreira

2059 Perdidos à vista da Costa. Trabalhos arqueológicos subaquáticos na Barra do Tejo Jorge Freire / José Bettencourt / Augusto Salgado

2071 Arqueologia marítima em Cabo Verde: enquadramento e primeiros resultados do projecto CONCHA

José Bettencourt / Adilson Dias / Carlos Lima / Christelle Chouzenoux / Cristóvão Fonseca / Dúnia Pereira / Gonçalo Lopes / Inês Coelho / Jaylson Monteiro / José Lima / Maria Eugénia Alves / Patrícia Carvalho / Tiago Silva

2085 Trabalhos arqueológicos na Cidade Velha (Ribeira Grande de Santiago, Cabo Verde): reflexões sobre um projecto de investigação e divulgação patrimonial André Teixeira / Jaylson Monteiro / Mariana Mateus / Nireide Tavares / Cristovão Fonseca / Gonçalo C. Lopes / Joana Bento Torres / Dúnia Pereira / André Bargão / Aurélie Mayer / Bruno Zélie / Carlos Lima / Christelle Chouzenoux / Inês Henriques / Inês Pinto Coelho / José Lima / Patrícia Carvalho / Tiago Silva

2103 A antiga fortificação de Quelba / Khor Kalba (E.A.U.). Resultados de quatro campanhas de escavações, problemáticas e perspectivas futuras Rui Carita / Rosa Varela Gomes / Mário Varela Gomes / Kamyar Kamyad

2123 Colónias para homens novos: arqueologia da colonização agrária fascista no noroeste ibérico Xurxo Ayán Vila / José Mạ . Señorán Martín 


\title{
CÍRCULOS SEGMENTADOS GRAVADOS NA BACIA DO RIO LIMA (NOROESTE DE PORTUGAL): CONTRIBUTOS PARA O SEU ESTUDO
}

\author{
Diogo Marinho ${ }^{1}$, Ana M.S. Bettencourt ${ }^{2}$, Hugo Aluai Sampaio ${ }^{3}$
}

\begin{abstract}
RESUMO
A arte rupestre como prática das comunidades do passado pode ser dividida em arte paleolítica e em arte pós-paleolítica. Este trabalho incidirá na arte pós-paleolítica de ar livre na qual se inserem, por sua vez, as Artes Atlântica e Esquemática entre outras difíceis de definir segundo Bettencourt (2017a, 2017b). É dentro destas últimas que se enquadra o nosso objeto de estudo, os círculos segmentados gravados que, de acordo com aquela autora, pertenceram a um universo estilístico emergente na Idade do Bronze. A área de estudo é a bacia do rio Lima onde, apesar de raros, estes motivos aparecem quer no litoral como no interior, em associação com diferentes gramáticas figurativas. Pela observação macroscópica da sua orientação indiciam relação com cultos celestes ou celebrações em determinados momentos do ano.
\end{abstract}

Palavras-chave: Arte Rupestre, Arte pós-paleolítica, Círculos segmentados gravados, Bacia do rio Lima.

\begin{abstract}
Rock art as a practice of past communities can be divided into Palaeolithic and post-Palaeolithic arts. Considering the later, which in turn can be divided into Atlantic and Schematic Arts, among other styles difficult to define (Bettencourt, 2017a, 2017b), this work will focus Atlantic rock art. Our selected object of study is the recorded segmented circles that, according to that author, will belong to a stylistic universe emerging in the Bronze Age. The geographic area is the Lima River basin. Although these motifs are rare, they appear both on the coast and inland, in association with different figurative grammars. By the macroscopic observation of its orientation they indicate a relation with celestial cults or celebrations during certain moments of the year.

Keywords: Rock Art, Post-paleolithic art, Engraved segmented circles, Lima River basin.
\end{abstract}

\section{INTRODUÇÃO}

A arte rupestre pós-paleolítica do Noroeste Ibérico é uma temática que tem vindo a ser amplamente trabalhada desde o século passado. Os primeiros trabalhos culminaram nas publicações de Obermaier (1923, 1925), seguido de Lopez Cuevillas (1943), Bosh-Gimpera (1954) e Anati (1968). Na segunda metade do séc. XX desenvolvem-se importantes trabalhos no território galego, com destaque para Peña Santos e colaboradores (Peña Santos e Vásquez Varela, 1979; Peña Santos e Rey García, 2001; Peña Santos e Costas Goberna, 2001, entre muitos outros), referindo-se à arte rupestre daquela região como Arte Galaico-Portuguesa. Numa primeira fase, esta arte foi caracterizada por combinações circulares como elemento predominante e mais comum, sendo posteriormente dividida em dois grupos: o naturalista e o geomé-

\footnotetext{
1. Mestrando em Arqueologia da Universidade do Minho, Braga; diogomarinhog81@gmail.com

2. Laboratório de Paisagens, Património e Território (Lab2PT); Departamento de História da Universidade do Minho, Braga, Portugal; anabett@uaum.uminho.pt

3. Escola Superior de Hotelaria e Turismo do Instituto Politécnico do Cávado e do Ave (ESHT/IPCA); Centro de Investigação, Desenvolvimento e Inovação em Turismo (CITur); hugoaluai@gmail.com
} 
trico (Peña Santos e Costas Goberna, 2001). O grupo naturalista incluía motivos de animais, antropomorfos e armas. O geométrico definia-se por combinações circulares, covinhas, círculos concêntricos, espirais e labirintos (Peña Santos, 1979; Peña Santos e Costas Goberna, 2001). Em termos cronológicos estes autores inseriam a Arte Galaico-Portuguesa na Idade do Bronze, entre a segunda metade do III milénio a.C. e os inícios do II milénio a.C.. Esta aproximação cronológica foi conseguida através das representações de armas, pois é neste período que se encontram as primeiras evidências materiais destes artefactos. Vázquez Varela (1983, p. 6) procedeu a uma subdivisão cronológica individualizando a datação de vários motivos. Esta subdivisão resultou em 11 grupos de motivos: (1) combinações circulares, datadas desde a cultura megalítica até à cultura castreja; (2) espirais, datadas do Calcolítico e Idade do Bronze; (3) labirintos, datados da fase final da Idade do Bronze; (4) cenas de equitação, datadas do Bronze Final; (5) serpentes, datadas da Idade do Bronze, podendo ser também atribuídas à Idade do Ferro; (6) figuras humanas, datadas da Idade do Bronze; $(7)$ idoliformes, datados do Calcolítico; (8) armas, datadas do Calcolítico até à Idade do Bronze; (9) paletas, datadas do período da Idade do Bronze Final; (10) covinhas, atribuídas a todos os períodos de arte rupestre; (11) cistas, datadas da Idade do Bronze Inicial.

Em Portugal, Baptista $(1983-1984,1986)$ propõe, na década de 1980, a divisão dos motivos gravados no Noroeste em dois grupos, os grupos I e II do Noroeste. O grupo I correspondia a manifestações rupestres, sobretudo litorais, e o grupo II a áreas mais interiores, diferenciando-se através da temática, técnica e cronologia. O grupo I tinha como elementos principais as composições circulares, figuras proto-labirínticas ou labirintiformes, espirais, em menor expressão, as armas, zoomorfos e antropomorfos, podendo aparecer em algumas estações idoliformes (Baptista, 1984). Este autor atribuiu-lhe uma cronologia da Idade do Bronze (Baptista, 1984). O grupo II caracteriza-se por incluir antropomorfos esquemáticos, quadrados e retângulos segmentados internamente, e círculos simples e ferradura, com ou sem covinha central. Motivos mais raros seriam os 'ganchos", pequenas espirais, podomorfos, paletas, suásticas, etc. (Baptista, 1984). A nível cronológico, o autor situa estas manifestações entre o Bronze Final e a Alta Idade Média (Baptista, 1984).

No início da década de 1990 investigações protago- nizadas por Richard Bradley e outros investigadores galegos e portugueses no Noroeste Ibérico culminaram num estudo exaustivo sobre a Arte Atlântica, designação esta usada para caracterizar as artes galaico-portuguesas e o grupo I do Noroeste (Bradley, 1997). Esta obra vai considerar a Arte Atlântica como manifestação emergente entre os finais do IV milénio e os inícios do III milénio a.C., com término na Idade do Bronze. No início do século XXI o autor escreve um importante artigo demonstrando a diferença entre Artes Atlântica e Esquemática no Noroeste, em especial no que concerne a acessibilidades e audiências (Bradley, 2002).

A designação de Arte Atlântica vem amplamente sendo adotada por muitos autores em Portugal, mas ainda sofre de certa resistência no território Galego. Já Alves (2003, 2009), perante o que se considera a originalidade da Arte Atlântica no Noroeste (com motivos zoomorfos e armas) preferiu o termo de arte de tradição atlântica. Esta autora recua a origem da Arte Atlântica para o IV milénio a.C., por comparação de alguns motivos com os existentes na arte megalítica. Esta cronologia foi, posterior e paulatinamente, adotada por vários outros autores (Dinis e Bettencourt, 2009; Santos-Estévez, 2012; Bettencourt, 2009; 2013; Cardoso, 2015, entre outros).

No que diz respeito à Arte Esquemática de ar livre, a necessidade da sua revisão tem sido defendida por alguns autores, nomeadamente Jorge (1986) e Alves e Reis (2009). Tal foi timidamente tentado por Cardoso (2015) e por Cardoso e Bettencourt (2015), para o caso específico da bacia do Ave, e por Bettencourt (2017a, 2017b) em termos mais generalistas. A subdivisão da Arte Esquemática de ar livre contempla, nestas propostas, duas fases. A primeira, inserível no Neolítico e no Calcolítico, inclui motivos antropomorfos esquemáticos, reticulados simples e complexos, soliformes e círculos simples. A segunda, inserível na Idade do Bronze e persistindo até à Idade do Ferro, caracteriza-se pela presença de motivos em "U'" ou semicirculares, com ou sem sulco e covinha central, e representações de falos.

Nestes trabalhos Bettencourt (2017a, 2017b) adota, ainda, a expressão de Arte Atlântica apenas para a sua primeira fase, precisamente a que tem afinidades com as artes identificadas no Reino Unido e Irlanda e considera que os restantes motivos existentes no Noroeste ibérico (armas, cervídeos, equídeos, barquiformes, círculos segmentados, paletas, podomorfos, entre outros) fazem parte de um ter- 
ceiro grupo, que terá surgido nos inícios da Idade do Bronze e que acompanha as alterações estruturais socioeconómicas ocorridas naquele período (Bettencourt, 2020). Este terceiro grupo, de difícil definição, mas designado de figurativo (Bettencourt, 2019), comporta motivos que podem estar associados a grafismos de Arte Atlântica ou de Arte Esquemática, mas que podem ocorrer em afloramentos ou áreas novas.

Atendendo a estes pressupostos, o objetivo geral deste trabalho é o estudo de um destes motivos em específico, os círculos segmentados gravados, cuja presença é rara no Noroeste Ibérico. A área escolhida para o seu estudo corresponde aos cursos inferior e médio da bacia do rio Lima, no Noroeste de Portugal, e ribeiras litorais que a integram.

$\mathrm{Na}$ perspetiva de contribuir para o estudo destes símbolos, definem-se como objetivos específicos deste trabalho (1) a inventariação dos lugares com esta simbologia no território delimitado; (2) o estudo da sua distribuição espacial, à macro escala de análise, com o intuito de identificar eventuais padrões de distribuição topográfica; (3) a descrição dos afloramentos gravados, à micro escala de análise, por forma a observar como se relacionam os círculos segmentados com outros símbolos, eventualmente contemporâneos, ou com símbolos típicos de outros estilos de arte rupestre e de outras cronologias; (4) o estudo da sua inter-relação com outros contextos arqueológicos considerados contemporâneos; e (5) o estudo da sua inter-relação com recursos naturais mineiros, nomeadamente o estanho, o ouro e a prata.

\section{METODOLOGIA}

Este trabalho foi iniciado com a pesquisa de gabinete através da consultou de bibliografia da especialidade sobre as problemáticas das artes rupestres do Noroeste Ibérico. Esta pesquisa foi alargada, também, a todas as publicações que contemplavam afloramentos gravados da bacia do Lima para identificar a presença de círculos segmentados. Recorreu-se, igualmente, ao Corpus Virtual de Arte Rupestre do Noroeste - CVARN (www.cvarn.org), assim como à base de dados que lhe deu origem e que tem sido várias vezes atualizada (ainda que muitas dessas atualizações ainda não estejam disponíveis online). Foi, também, consultada cartografia, nomeadamente, as Cartas Militares de Portugal folhas nํ..27 e 40, à esca- la 1:25000, e as Cartas Geológicas de Portugal, folhas no. . 1-C, 1-D, 5-A e 5-B, à escala 1:500oo, relativas à área de influência da bacia do rio Lima. $\mathrm{O}$ trabalho de campo foi limitado, atendendo à conjuntura atual imposta pela presença do vírus COVID-19, mas foi realizada a visita a alguns afloramentos gravados, como Chã da Rapada 3 (Ponte da Barca). Com esta visita foi possível recolher dados que se mostraram pertinentes para o presente estudo. Por fim, a utilização de Sistemas de Informação Geográfica (SIG) auxiliou na análise da distribuição espacial dos afloramentos gravados e da sua relação com diferentes variáveis consideradas.

Teoricamente foi tida em consideração que o conhecimento é subjetivo e interpretativo, assente num conjunto de dados empíricos e que a arte rupestre é uma manifestação das comunidades que reflete o seu universo ideológico e a sua interação com o espaço que vivenciaram e experienciaram.

\section{OS DADOS}

\subsection{Inventário}

O inventário teve em conta os seguintes sete critérios: (1) localização administrativa; (2) coordenadas geográficas decimais do local segundo o sistema WGS 84 e altimetria; (3) localização física e ambiental dos afloramentos; (4) contexto arqueológico; (5) descrição dos afloramentos e da distribuição dos motivos; (6) descrição da técnica de gravação observada; e (7) estado de conservação.

\subsubsection{Concelho de Arcos de Valdevez}

\section{Gião 1 - rocha 1 e rocha 15}

Lugar: Gião; Freguesia: Cabana Maior.

Latitude: 40.605318. Longitude: -8.135474.

Altitude: cerca de 800 metros.

Localização física e ambiental: o sítio arqueológico localiza-se na margem direita do rio Lima e permite ser visualizado a grande distância. Trata-se de uma bacia de receção do ribeiro do Gião «encimada por dois cumes [...] unidos por uma cumeada mais baixa» (Alves, 2013a, p. 155), com boa visibilidade para o vale do Lima. Corresponde a uma área de lameiros, com inúmeros afloramentos e blocos erráticos graníticos cujo uso ancestral e persistente no tempo ainda hoje pode ser verificado, através de práticas de pastorícia (Alves, 2013a).

Descrição: o sítio do Gião corresponde a um espa- 
ço onde ocorrem mais de 100 afloramentos gravados, predominantemente com motivos inseríveis na Arte Esquemática de ar livre, entre outros possivelmente de época histórica. Foi descoberto por António Martinho Baptista. Este espaço encontra-se dividido em dois núcleos: Gião 1 e Gião 2, sendo na rocha 1 do núcleo 1 que se encontra o afloramento com os círculos segmentados (objeto de estudo deste trabalho).

A rocha 1 do Gião corresponde a um grande afloramento onde se inscreve um singular motivo antropomórfico em fi, com a cabeça marcada por uma covinha, braços adossados a dois retângulos da extremidade dos quais saem duas mãos, com palma e dedos bem marcados (Baptista, 1986) (Figura 1). Neste afloramento ocorrem, ainda, muitos motivos inseríveis na Arte Esquemática, como antropomorfos e quadrados e retângulos segmentados. Destaca-se, ainda, a presença de ovais segmentadas, covinhas, círculos simples e cruciformes, entre os quais dois círculos segmentados em quatro partes. O outro círculo segmentado encontra-se no meio de várias composições reticuladas, ocupando o topo do já referido motivo antropomórfico em fi com a cabeça marcada por uma covinha. Os segmentos de ambos os círculos orientam-se na mesma direção, ainda que para já não tenha sido possível verificar in loco essa direção.

$\mathrm{Na}$ rocha 15 do Gião observa-se apenas um círculo segmentado posicionado no centro do afloramento, na sua pendente oeste, estando os seus segmentos orientados para NNE-SSO e para E-O. Neste afloramento existem, ainda, vários motivos ovais, quadrados e retângulos, todos eles segmentados, podendo por vezes incorporar figuras complexas, além de cruciformes.

A técnica de gravação é o picotado seguido de abrasão. Estado de conservação: razoável em termos arqueológicas e excelente em termos paisagísticos e ambientais (Sá, 2015).

Bibliografia: Baptista, 1983-84; Alves, 2013; Sá, 2015.

\section{Pedra da Costa 1}

Lugar: Castro; Freguesia: Álvora.

Latitude: 41.937358. Longitude: -8.452223 .

Altitude: cerca de 238 metros.

Localização física e ambiental: ocupa um pequeno patamar no alto da vertente oeste do Monte do Castro, sobranceiro ao ribeiro de Frades (Figura 2), afluente do rio Vez e para o qual tem boa visibilidade.
O local tem intensa vegetação arbustiva, composta por giestas. Nas proximidades há algumas árvores. Contexto arqueológico: no topo do Monte do Castro ocorreu ocupação datada da Idade do Bronze Final (Bettencourt, 1988), entre outras da Idade do Ferro (Castro de Álvora).

Descrição: A Pedra da Costa I está classificada como Imóvel de Interesse Público (IIP) e, apesar de ser conhecida desde a década de 1980 (Baptista, 1986a, 1986b), só foi alvo de descrição mais detalhada por Sá (2015). Segundo a autora, corresponde a um afloramento granítico de cor cinzenta escura, com manchas esbranquiçadas (dada a ação dos incêndios). De grandes dimensões, encontra-se pouco destacado do solo. A sua superfície é tendencialmente aplanada, ainda que ligeiramente inclinado para oeste, e tem uma concavidade natural. Mede 4,63 $\mathrm{m}$ de comprimento por 3,66 m de largura, estando fraturado a nascente.

A sua superfície superior está profusamente gravada com composições circulares e nuvens de pontos. $\mathrm{Na}$ extremidade sul encontra-se um círculo concêntrico de duas voltas com o interior composto por nuvens de pontos. A partir do centro deste motivo sai um sulco longo e curvilíneo que percorre parte da superfície gravada e que se vai unir a um círculo concêntrico de duas voltas, existente, sensivelmente, a meio do afloramento. Deste sulco parte outro que vai sobrepor-se a uma figura retangular de cantos arredondados, preenchida por nuvens de pontos, que se encontra na extremidade oeste do afloramento. Há ainda a registar, a oeste, um círculo segmentado em quatro partes (Figura 2). Uma vez que este afloramento se encontra parcialmente coberto por sedimentos a su-sudeste e nor-nordeste, é provável que existam outras gravuras ainda soterradas. A técnica de gravação é o picotado seguido de abrasão.

Estado de conservação: O afloramento encontra-se com a cor alterada devido à acção de incêndios e pela presença de líquenes que, por sua vez, cobrem parte das gravuras. Existe ainda uma fratura do afloramento orientada a este (Sá, 2015, p. 43).

Bibliografia: Baptista, 1986a; 1986b; Sá, 2015.

\subsubsection{Concelho de Ponte da Barca}

\section{Chã da Rapada $3^{4}$}

Lugar: Britelo; Freguesia: Britelo.

4. Segundo a designação de Alves, 2012. 
Latitude: 41.83452. Longitude: -8.281541.

Altitude: cerca de 300 metros.

Localização física e ambiental: a Chã da Rapada ocupa o interior do Parque da Peneda-Gerês, situando-se numa plataforma da vertente noroeste da serra Amarela, na margem direita do rio Lima. Trata-se de uma área com densa concentração de afloramentos graníticos direcionados de noroeste para sudeste. Do local a visibilidade é reduzida no sentido norte e sul - onde se encontram as vertentes das serras do Soajo e Amarela -, ao contrário do que ocorre para poente, onde a visibilidade é mais alargada, nomeadamente, para o Monte do Castelo de Aboim da Nóbrega, já no concelho de Vila Verde (Bettencourt 2013a).

Contexto arqueológico: a cotas superiores há a registar a necrópole megalítica de Britelo.

Descrição: Neste sítio arqueológico foram identificadas inúmeras gravuras rupestres, algumas delas alvo de decalques e descritas (Baptista, 1986a, 1986b, 1997; Martins, 2006; Alves, 2012). Em 2012, Alves publica o decalque do que designa por rocha 3 da Chã da Rapada, descrevendo os motivos presentes e a sua disposição no afloramento. Trata-se de um afloramento de cor acinzentada, rasante ao solo, estando perto de outros afloramentos gravados. Tem cerca de 5 metros no sentido nordeste/sudoeste e cerca de 4,50 metros no sentido noroeste/sudeste.

Encontra-se profusamente gravado, possuindo alguns motivos que se inserem na Arte Esquemática, entre outros, mais raros e atípicos (Figura 3). No contexto da Arte Esquemática podem der inseríveis dois quadrados segmentados, cinco sulcos meandriformes rematados por uma covinha numa das extremidades (serpentiformes?) e dois eventuais antropomorfos, muito esquematizados. No âmbito de outros motivos há a registar, ainda, sete pentagramas, cinco quadrados concêntricos (por vezes segmentados em alguns lados, podendo ter sido transformados em tabuleiros de jogo), inúmeras covinhas um pouco por todo o afloramento, por vezes, sobrepondo-se aos quadrados concêntricos, um motivo sub-retangular com uma extremidade triangular de onde sai um sulco que se sobrepõe a um quadrado concêntrico, e três cruzes latinas e uma grega. Neste conjunto há a destacar dois círculos segmentados, algo distantes entre si. Em visita ao local verificou-se que um deles, situado na pendente sul, foi gravado entre dois quadrados segmentados, a que se associou um conjunto de cinco pentagramas. O outro, posicionado na extremidade oposta, na pendente nordeste, foi associado a outros dois pentagramas. Nesta área do afloramento, em posição periférica, encontra-se uma figura retangular segmentada de forma irregular que poderá ser contemporânea dos círculos segmentados. Os segmentos que subdividem estes motivos estão orientados de forma distinta. O círculo segmentado posicionado na vertente sul possui os seus segmentos orientados para norte-sul e este-oeste, encontrando-se bastante erodido. O círculo segmentado que se situa na pendente nordeste, possui os seus segmentos orientados para noroeste-sudeste/sudoeste-nordeste.

A técnica de gravação utilizada foi o picotado seguido de abrasão.

Estado de conservação: Razoável.

Bibliografia: Alves, 2012; Bettencourt, 2014 e dados inéditos.

\subsubsection{Concelho de Viana do Castelo}

\section{Breia 1}

Lugar: Portela; Freguesia: União de Freguesias de Cardielos e Serreleis.

Latitude: 41.721667. Longitude: 8.733333 .

Altitude: cerca de 54 metros.

Localização física e ambiental: ocupa um patamar na base da vertente este-sudeste do Monte de São Silvestre, sobranceiro a um curso de água intermitente que vai desaguar à ribeira de Nogueira, afluente do Lima. Trata-se, ainda, de uma área profusamente irrigada pelos cursos de água intermitentes que se formam nas partes altas do monte, sendo frequente que o afloramento gravado fique inundado. Descrição: a Breia 1 foi encontrada por Francisco Queiroga e estudada por Bettencourt (2013, 2014) e por Bettencourt e Santos-Estévez (2018). Caracteriza-se por ser um afloramento de granito de grão médio, rasante ao solo, de cor esbranquiçada e com algumas manchas negras devido à ação do fogo sobre os líquenes. Possui algumas manchas alaranjadas, possivelmente relacionadas com a presença de nódulos de ferro oxidado.

Este afloramento é de grandes dimensões $(16,40$ metros de comprimento, na direção este-oeste, por 11,8 metros de largura, no sentido norte-sul). Encontra-se profusamente gravado com motivos de Arte Atlântica clássica, entre outros motivos que se afastam desta gramática decorativa (Bettencourt, 2017a, 2017b). Segundo Bettencourte Santos-Estévez (2018, 
p. 27) subdivide-se em sete painéis, possuindo círculos segmentados gravados nos painéis 1,2 e 7 . O painel 1 possui um contorno triangular, posicionando-se a nordeste do afloramento, na área mais elevada. Apresenta uma densidade de motivos circulares, unidos por linhas sinuosas que parecem estar em conexão com uma figura idoliforme. Esta figura tem um contorno trapezoidal, fazendo lembrar uma figura antropomórfica, estando segmentada no seu interior. A maioria dos motivos são círculos concêntricos, com covinha central e de diferentes dimensões. De alguns destes motivos saem sulcos para as diaclases ou extremidades do afloramento. Há, ainda, dois sulcos meandriformes isolados na extremidade norte, podendo ser considerados serpentiformes. $\mathrm{Na}$ base do afloramento surgem quatro equídeos esquemáticos isolados, orientados a nascente. A norte do painel, encontra-se um quadrúpede muito esquemático, possivelmente um cervídeo. O seu dorso parece ter sido aproveitado como segmento de um círculo segmentado (Bettencourt e Santos-Estévez, 2018, p. 28), motivo este que se encontra a norte do painel, estando os seus segmentos orientados para noroeste-sudeste e nordeste-sudoeste (Bettencourt e Santos-Estévez, 2018, p. 29). O painel 2, de contorno hexagonal, fica a uma cota mais baixa em relação ao painel 1. Tem 4,30 metros sentido este-oeste e 3,50 sentido norte-sul. Caracteriza-se por ter, na sua maioria, composições circulares inseríveis na Arte Atlântica (Bettencourt, 2013; 2014; Bettencourt e Santos-Estévez, 2018, p. 28). No quadrante sudeste, surgem, pelo menos, quatro círculos segmentados, dois deles muito erodidos. Três destes motivos encontram-se na parte inferior do painel e um localiza-se na parte central do mesmo. Os seus segmentos orientam-se de noroeste-sudeste para sudoeste-nordeste, no que diz respeito dos dois casos posicionados na área inferior a sudeste do painel. Os outros dois casos localizam-se na parte inferior e central do painel, a este/sudeste, na periferia dos restantes motivos que nele figuram. Nestes, apenas se consegue percecionar a orientação dos segmentos de um dos casos, estando estes orientados de nordeste-sudoeste e de este-oeste.

O painel 7, descoberto e descrito recentemente (Bettencourt e Santos-Estévez, 2018, p. 31), situa-se na extremidade sudeste do afloramento e é mais elevado do que os painéis 3, 5 e 6 . Mede 6,30 metros no sentido Este-oeste por 4,20 metros no sentido norte-sul, embora esteja parcialmente fraturado. Tal- vez com exceção de um círculo, neste painel não se encontram motivos de Arte Atlântica clássica, mas apenas motivos "figurativos" com base na conceção de Bettencourt (2017a, 2017b, 2019). Observam-se, também, dois quadrúpedes, um esquemático e um semi-naturalista. O quadrúpede esquemático apresenta hastes ou orelhas pronunciadas e dirige-se para nordeste e transporta um símbolo circular no dorso. Está associada a um círculo segmentado, com os segmentos orientados para nordeste-sudoeste e para noroeste-sudeste. De destacar, ainda, a gravação de um podomorfo calçado neste painel.

A técnica de gravação utilizada foi a percussão seguida de abrasão, excetuando a gravação de um equídeo, que ocorreu em baixo-relevo. Alguns círculos segmentados, por exemplo, o do painel 1, têm um sulco menos largo do que a maioria dos motivos atlânticos. Estado de conservação: razoável, no geral, mas com áreas muito erodidas e com estalamentos antigos (Bettencourt e Santos-Estévez, 2018, p. 25).

Bibliografia: Bettencourt, 2013; 2014; Bettencourt e Santos-Estévez, 2018.

\section{Breia 5}

Lugar: Portela; Freguesia: União de Freguesias de Cardielos e Serreleis.

Latitude: 41.721667. Longitude: 8.733333.

Altitude: cerca de 86 metros.

Localização física e ambiental: localiza-se numa depressão, a meio da vertente este-sudeste do Monte São Silvestre, numa zona profundamente irrigada, por onde passa um curso de água intermitente. Trata-se de uma área com um substrato geológico predominantemente granítico onde ocorrem, também, diversos veios de quartzo leitoso. Nas proximidades encontram-se jazidas primárias e secundárias de estanho. O solo apresenta uma escassa profundidade, com vegetação predominantemente arbustiva (tojo, giesta) e herbácea. Atualmente a utilização do terreno é florestal, tendo sido área de pastoreio, até ao século XX. O local também foi usado para corte de pedra manual. Possui visibilidade fechada em todas as direções. com a exceção do quadrante sul, onde se pode observar parte do vale do rio Lima (Bettencourt e Santos-Estevez, 2018, p.55).

Descrição: recentemente publicado por Bettencourt e Santos-Estévez (2018), embora tivesse sido referido em vários trabalhos, com mais ou menos detalhe (Bettencourt, 2017a, 2017b, 2018), trata-se de um afloramento de granito de grão médio, de cor acin- 
zentada, orientado de noroeste para sudeste, de contorno sub-retangular, com elevação na parte central e em grande parte do seu eixo maior, de onde partem alguns declives acentuados para todos os quadrantes, excetuando o noroeste. É de grandes dimensões: 13 metros de comprimento, por 4 metros de largura e 1 metro de altura máxima.

O afloramento possui dois painéis, incluindo apenas no painel 1 a gravação de um círculo segmentado. Com efeito, este painel distribui-se no topo do afloramento e tem os seus declives orientados a sudoeste, sul e sudeste, numa área de 6,4 metros de comprimento por 4 metros de largura.

Neste painel, Bettencourt e Santos-Estévez (2018, p. 55-57) contabilizaram cerca de onze equídeos semi-naturalistas e um esquemático. Oito desses equídeos estão orientados para noroeste e, pelo menos três, estão orientados para sudeste. No topo de afloramento parecem existir mais dois equídeos incompletos. Em associação com o grupo de equídeos que se dirigem para sudeste, surge um círculo segmentado, com os segmentos orientados para nordeste-sudoeste e noroeste-sudeste (Figura 4).

A técnica de gravação utilizada foi a percussão seguida de abrasão.

Estado de conservação: Este afloramento encontra-se em estado grave de degradação, com vários estalamentos devido à ação de sucessivos incêndios. Bibliografia: Bettencourt 2017a, Bettencourt 2017b, Bettencourt e Santos-Estévez, 2018.

\section{Breia 9}

Lugar: Portela; Freguesia: União de Freguesias de Cardielos e Serreleis.

Latitude: 41.721667. Longitude: 8.733333 .

Altitude: cerca de 86 metros.

Localização física e ambiental: ocupa uma plataforma na parte inferior da vertente este-sudeste do Monte São Silvestre. Trata-se de uma área com substrato geológico predominantemente granítico onde ocorrem, também, diversos veios de quartzo leitoso. Nas proximidades encontram-se jazidas primárias e secundárias de estanho. O solo apresenta uma escassa profundidade, com vegetação arbustiva (tojo, giesta), arbórea (eucalipto) e herbácea. Atualmente a utilização do terreno é florestal, tendo sido área de pastoreio até ao século XX. A visibilidade para norte e noroeste é fechada, ainda que para oeste se aviste a vertente íngreme do Monte de São Silvestre. O vale do Lima é visível desde entre os quadrantes sudoeste e este (Bettencourt e Santos-Estévez, 2018, p. 70). Descrição: afloramento descoberto e publicado recentemente (Bettencourt e Santos-Estevez, 2018, p. 70-71). É de granito de grão médio, de cor acinzentada, de médias dimensões, algo destacado do solo. Tem uma parte mais elevada e aplanada, que desenvolve um declive para sul, este e oeste e mais acentuada para noroeste. Possui uma concavidade na orientação do afloramento. Atualmente, passa-lhe por cima um muro de divisão de propriedade, orientado de noroeste para sudeste.

O afloramento possui dois painéis, estando os círculos segmentados gravados, apenas, no painel 1 .

O painel 1 encontra-se na extremidade sudeste do afloramento, presente na área aplanada e dos declives norte e nordeste. Apresenta uma figura oval com eixo nordeste-sudoeste, subdividido por um sulco com covinha na extremidade sudoeste. No seu interior existem três sulcos perpendiculares que segmentam a figura. $\mathrm{Na}$ extremidade nordeste sai um sulco que se liga a um motivo tendencialmente circular. Dentro deste último encontram-se dois círculos segmentados, unidos entre si e partilhando um sulco na convergência dos mesmos. O círculo segmentado ligeiramente maior tem os seus segmentos orientados para norte-sul e este-oeste e os segmentos do círculo segmentado mais pequeno estão orientados para nordeste-sudoeste e noroeste-sudeste. Nas imediações destes motivos ocorre o que parece ser outro círculo segmentado, com os seus segmentos orientados para noroeste-sudeste e nordeste-sudoeste, apresentando-se bastante erodido e estando associado a um círculo aberto. A vertente noroeste, com declive bastante acentuado, inclui um soliforme rodeado por um círculo incompleto. Dele sai um sulco que se prolonga até à diáclase, como se estivesse a entrar dentro do afloramento, e volta a sair através de um sulco divergente (Figura 4).

Estas gravuras foram feitas através da técnica de percussão seguidas de abrasão.

Estado de conservação: Razoável.

Bibliografia: Bettencourt e Santos-Estévez, 2018.

\section{Figueiró 1 e 2}

Lugar: Troviscoso; Freguesia: Carreço.

Latitude: 41.737222 . Longitude: -8.858889 .

Altitude: cerca de 60 metros.

Localização física e ambiental: o grupo de gravuras rupestres do Figueiró ocupa numa plataforma da base da vertente oeste da serra de Santa Luzia, em 
local com grande visibilidade para a plataforma litoral e o Oceano Atlântico, a oeste, sudoeste e sul, e para a colina de Montedor, a norte e a noroeste. Nos restantes quadrantes erguem-se, imponentes, as vertentes íngremes da serra de Santa Luzia. Atualmente estes afloramentos encontram-se no meio do casario de Troviscoso, no interior de uma propriedade privada (Bettencourt e Santos, 2014).

Contexto arqueológico: existência do túmulo da Idade do Bronze da Cova da Moura, em Carreço (Viana, 1955; Bettencourt, 2013).

Descrição: Este sítio foi publicado por Viana (1960) e contextualizado por Bettencourt e Santos (2014). Inicialmente era constituído por três afloramentos gravados, porém restam apenas dois - Figueiró 1 e 2. Figueiró 1 corresponde a um afloramento de granito de grão grosseiro, destacado do solo, com cerca de 5,50 metros de altura por cerca de 10 metros de comprimento, no sentido este-oeste. Nos desenhos de Viana (1960) observa-se um círculo concêntrico, em relevo, de estilística atlântica clássica, dois círculos simples, quatro motivos ovalados ou grosseiramente retangulares preenchidos por grelhas irregulares e 8 círculos segmentados. Um deste localiza-se na pendente sul do afloramento, quatro na pendente este e três na pendente oeste. Sete destes motivos segmentam-se em quatro partes enquanto um se segmenta em cinco partes (Figura 5).

Figueiró 2, relativamente perto de Figueiró 1, também é de grandes dimensões e apresenta grande declive. Encontra-se bastante degradado devido a atos de vandalismo. Segundo Viana (1960) os motivos existentes consistiam em grandes sulcos lineares e sinuosos, covinhas, uma composição quadrangular reticulada, uma espiral, uma figura retangular internamente segmentada e vários círculos segmentados. A técnica utilizada parece ter sido a percussão seguida de abrasão e, num caso, o alto relevo.

Estado de conservação: Desconhecido.

Bibliografia: Viana, 196o; Bettencourt e Santos 2014.

\section{Laje da Churra}

Lugar: Paçô; Freguesia: Carreço.

Latitude: 41.756353. Longitude: 8.860318.

Altitude: cerca de 80 metros

Localização física e ambiental: a Laje da Churra situa-se no sopé da vertente oeste da serra de Santa Luzia. Fica sobranceira ao ribeiro da Fonte Quente, que desagua diretamente no oceano.

Contexto arqueológico: Túmulo da Idade do Bron- ze da Cova da Moura, em Carreço (Viana, 1955; Bettencourt, 2013); povoado do Bronze Final de Santo António, em Afife, a cerca de 2,7 km (Bettencourt, 2013; Oliveira e Bettencourt, 2020).

Descrição: A Laje da Churra foi descoberta pelo Padre Lourenço em 1973 e estudada monograficamente por Santos (2014). Trata-se de um afloramento de granito porfiróide, de grão fino a médio fino, de grandes dimensões, sobrelevado, sendo aquele que tem maior número de gravuras rupestres na Serra da Santa Luzia. Isto traduz-se num total de 19 painéis, sendo os painéis 2, 3, 5, 6, 8 e 11b os que contêm círculos segmentados. Trata-se, de uma forma geral, de um afloramento com escassíssimos motivos de gramática atlântica (espirais, semicírculo concêntrico e um esteliforme) e, pelo contrário, inúmeros motivos figurativos segundo a conceção de Bettencourt (2017a, 2017b). Entre muitos outros destacam-se diferentes tipos de barquiformes, armas (alabardas), ferramentas (machados), animais marinhos (golfinhos), animais terrestres (equídeos), antropomorfos, paletas de diferentes tipos, covinhas com apêndices, covinhas.

O painel 2 situa-se na parte norte do afloramento. As gravuras neste painel são pouco percetíveis e materializam algumas covinhas dispersas, podendo ser associadas a sulcos orientados para várias direções. O painel inclui uma nuvem de pontos a sudeste associada a uma paleta. Os motivos principais do painel são as composições circulares (Santos, 2014, p. 52). Por fim, surge um círculo de grandes dimensões segmentado em três partes, localizado sensivelmente no centro do painel. Este motivo tem os seus segmentos orientados para noroeste-sudeste e para nordeste. A este motivo estão associados dois sulcos rematados por covinhas, que se unem formando uma figura complexa. Este motivo parece ter sido sobreposto a sudeste (Figura 6).

O painel 3 localiza-se no extremo nordeste do afloramento, numa área de declive. Neste painel os círculos segmentados aparecem em grande número, sendo nove no total (Santos, 2014, p. 53). Cinco destes motivos situam-se no centro do painel e apresentam-se segmentados em quatro partes, estando os seus segmentos orientados de nordeste-sudoeste e de noroeste-sudeste. $\mathrm{Na}$ extremidade este há mais dois círculos segmentados: um segmentado em quatro partes, com sulco exterior, estando os seus segmentos orientados para nordeste-sudoeste e este-oeste, e um outro motivo que inicialmente foi segmentado 
em quatro partes, porém, fruto de adições, passou a ser segmentado em seis partes, estando os seus segmentos orientados para noroeste-sudeste e sudoeste-nordeste. Na extremidade oeste do painel, observa-se um círculo segmentado com sulco exterior, com os segmentos orientados para noroeste-sudeste e sudoeste-nordeste. Existe ainda nesta área um outro círculo segmentado, com sulco exterior, apenas com um segmento, estando este orientado para noroeste-sudeste. Associados a estes motivos existem paletas, antropomorfos, quadrúpedes esquemáticos (um canídeo e um equídeo montado), um semicírculo concêntrico, covinhas, covinhas associadas a sulcos, entre outros sulcos emaranhados (Figura 6). O painel 5 ocupa o topo do afloramento. A sua iconografia gira em torno de possíveis paletas, covinhas, covinhas associadas a sulcos, um possível soliforme em baixo relevo e dois círculos segmentados (Santos, 2014, p. 55). Destes últimos, um ocupa a extremidade nordeste, estando segmentado em seis partes e os seus segmentos orientados para noroeste-sudeste, sudoeste-nordeste e su-sudoeste-nor-nodeste; na extremidade sudoeste surge outro círculo, também segmentado em quatro partes, com os seus segmentos orientados para noroeste-sudeste e sudoeste-nordeste, estando, igualmente, associados a paletas e covinhas (Figura 6).

O painel 6 posiciona-se na pendente este em relação aos painéis 3,5 e 7 . Este painel inclui uma complexidade de motivos. A nascente figuram três círculos segmentados: dois subdivididos em quatro partes, estando os segmentos orientados para nordeste-sudoeste e noroeste-sudeste; um segmentado em três partes, estando o sulco completo orientado para nordeste-sudoeste e o sulco parcial para sudeste-noroeste. Estes motivos estão associados a um conjunto de sulcos que materializam figuras complexas, talvez devido a sobreposições, barquiformes de tipo canoa, um golfinho, covinhas, covinhas associadas a sulcos e uma espiral interrompida (Santos, 2014, p. 56) (Figura 6).

O painel 8 encontra-se numa zona de declive. A norte fica o painel 6 e, a noroeste e oeste, o painel 7 . Possui dois círculos segmentados em quatro partes. Ambos possuem um sulco exterior. O sulco vertical de ambos está sensivelmente orientado para norte-sul, enquanto o sulco horizontal do círculo inferior está orientado para oeste-este e o do círculo superior para nordeste-noroeste. Estes motivos encontram-se associados a covinhas, sulcos rectilíneos, orien- tados para este-oeste. De referir, também, a presença de um motivo em forma de "T" (Santos, 2014, p. 58). O painel 11 está subdividido em três, sendo apenas o painel $11 b$ o que possui círculos segmentados, sensivelmente a meio da pendente do painel 11. A sua iconografia é variada, observando-se quatro grupos de motivos. Na parte mais elevada, a norte, ocorrem, sobretudo, sulcos, covinhas associadas a sulcos, uma espiral, composições circulares e um barquiforme de tipo canoa. Destaca-se um círculo segmentado em sete partes, localizado numa zona central deste grupo, a norte. Os segmentos encontram-se orientados para nordeste-sudoeste, noroeste-sudeste, sudoeste-nordeste e este-oeste. Figura, também, um outro círculo segmentado subdividido em três partes, com os segmentos orientados para noroeste-sudeste e sudoeste-nordeste. Associados a estes dois círculos segmentados ocorre uma espiral. A sul deste painel ocorrem outros motivos, heterogéneos, alguns deles podendo ser produto de sobreposições. Destacam-se uma espiral, um serpentiforme, uma paleta circular com cabo meandriforme, quadrúpedes, barquiformes de diferentes tipologias e inúmeras covinhas, por vezes alinhadas (Santos, 2014, p. 63).

A técnica utilizada nos variados painéis foi basicamente a percussão seguida de abrasão correspondendo a $98 \%$ da gravação neste afloramento. Os restantes motivos são em baixo relevo.

Estado de conservação: Razoável.

Bibliografia: Santos, 2014.

\section{DISCUSSÃO DOS DADOS E INTERPRETAÇÕES}

Foram inventariados dez afloramentos gravados com círculos segmentados distribuídos por seis núcleos distintos e posicionados na bacia do Lima, três deles no curso médio e outros três no curso inferior (Figura 7). No curso médio há três núcleos e quatro afloramentos de caráter interior; são eles: Chã da Rapada 3, situada na margem esquerda do rio Lima, e Gião 1 (rochas 1 e 15) e Pedra da Costa 1, ambos situados na margem direita do rio Lima. Uma das características comum aos três sítios é a sua localização em altitudes elevadas, oscilando estas entre os 230 e os 800 metros, sendo Gião 1 o que se encontra mais elevado. Chã da Rapada 3 e Pedra da Costa 1 caracterizam-se por estar no topo ou a meio de vertentes viradas a noroeste e oeste, enquanto Gião 1 está localizado na base da bacia de receção do ribeiro 
do Gião. Em todos estes locais há solos irrigados nas proximidades. Chã da Rapada 3 está próximo do rio Froufe. Pedra do Costa 1 está, de igual forma, associado ao vale do ribeiro de Frades, existente nas suas proximidades e para o qual tem visibilidade. Gião 1 caracteriza-se por estar associado à nascente do ribeiro do Gião, em área com inúmeros lameiros e com controlo visual muito superior aos outros dois afloramentos, sobre o meio circundante.

No curso inferior do rio Lima existem três núcleos gravados com círculos segmentados, distribuídos por seis afloramentos, a saber: Breia 1, 5 e 9, Figueiró 1 e 2 e Laje da Churra, todos eles situados na margem direita do rio Lima (Figura 7). A característica que impera em todos estes afloramentos é a sua localização, em locais de pouca altitude, que oscilam entre 50 a 100 metros.

Os afloramentos do núcleo da Breia localizam-se quer na base da vertente sudeste do Monte de São Silvestre (Breia 1) quer a meio da vertente sudeste (Breia 5 e 9), estando vinculados com cursos de água intermitentes e lameiros. Já a Laje da Churra e Figueiró 1 e 2 localizam-se no sopé da vertente oeste da serra de Santa Luzia, também em áreas profusamente irrigadas e vinculadas com a plataforma litoral. De salientar a Laje da Churra, na base da qual passa o ribeiro da Fonte Quente.

À micro escala de análise pode afirmar-se que os círculos segmentados nunca aparecem como motivo único nos afloramentos onde se manifestam. Num caso aparecem na periferia de motivos de Arte Atlântica clássica (Pedra da Costa 1); noutro caso surgem num afloramento que, sendo gravado maioritariamente com Arte Atlântica clássica, apresenta igualmente outros motivos, como equídeos, podomorfos, etc. (Breia 1); em três casos surgem em afloramentos com escassos motivos atlânticos clássicos e outros tipos de motivos (Laje da Churra, Figueiró I e 2); noutros três casos ocorrem em afloramentos com motivos esquemáticos (rochas 1 e 15 de Gião 1 , e Chã da Rapada 3); num caso associam-se a equídeos sub-naturalistas (Breia 5) e noutro caso associam-se a motivos de difícil classificação (Breia 9). Assim, parece não existir uniformidade em relação aos motivos ou gramáticas estilísticas a que se associam. No entanto, verifica-se que, nos casos em que ocorrem em afloramentos com motivos atlânticos clássicos e esquemáticos, localizam-se quer na periferia dos painéis (Breia 1, Pedra da Costa 1) quer em posição que parece quebrar a lógica ou a harmonia inicial do conjunto gravado (rochas 1 e 15 de Gião 1 e Chã da Rapada 3), como se tivessem sido gravados posteriormente.

Nos casos em que surgem associados a equídeos sub-naturalistas e a motivos raros que podem ser contemporâneos, observa-se diferenças, sendo que a característica que se destaca é o grau de integração dos círculos segmentados nas composições. Tal é o caso da Breia 5, onde vários equídeos se articulam com um círculo segmentado que, por se encontrar numa posição superior aos equídeos, parece funcionar com um guia, indiciando a hipótese de materializarem o culto do cavalo solar existente noutras áreas da Europa Atlântica (Bettencourt e Santos-Estévez, 2018, p. 57; Bettencourt, 2019). Na Breia 9, os dois círculos segmentados integram uma composição, encontrando-se dentro de um motivo circular, mas com os segmentos orientados em direções diferentes. A esta composição associa-se um soliforme, podendo deste modo existir uma conexão entre os dois motivos, indiciando, novamente, a metaforização de um culto solar.

No caso da Laje da Churra constata-se que a disposição dos círculos segmentados nos painéis adota duas formas distintas: na periferia e no centro das composições. Nos painéis onde surgem numa área central, assumem o papel principal da composição, estando apenas associados a covinhas e sulcos (painéis 2 e 8). Com efeito, há composições na qual a sua expressão é maioritária (painel 3). Nos painéis onde estes motivos surgem numa área periférica (painéis 5 e 6), observa-se que existe um distanciamento propositado em relação a outros motivos e uma certa lógica na composição, onde os círculos segmentados parecem estabelecer, intencionalmente, os limites das composições. Bettencourt (2017a, 2017b, 2019) considera que muitos dos motivos que ocorrem nestes painéis, como barquiformes, por exemplo, poderão ser contemporâneos dos círculos segmentados. A grande concentração destes motivos a nordeste parece indiciar, segundo Santos (2014), uma área de concentração de motivos que poderão transmitir significados de histórias reais ou míticas do mundo dos vivos, podendo ainda ser associados a códigos, lugares cerimoniais, realçando assim a importância do culto solar (Santos, 2014, p. 113-114). No caso de Figueiró 1, embora com as reservas que um desenho antigo implica, nota-se a concentração de círculos segmentados a oeste e este do afloramento, com apenas um a sul, o que parece indiciar uma 
composição relativamente uniforme e intencional, talvez, relacionada, igualmente, com o ciclo solar. Com efeito, estes dados abonam a favor da hipótese cronológica apresentada anteriormente por um dos autores deste texto (Bettencourt, 2017a; 2017b), que defende que os círculos segmentados são posteriores à Arte Atlântica clássica e à Arte Esquemática antiga, representando uma imagética da Idade do Bronze.

Se aceitarmos a premissa de que estes símbolos são da Idade do Bronze, verifica-se que em sete casos se localizam nas imediações de vestígios deste período cronológico. Referimo-nos à Breia 1, 5 e 9; Figueiró 1 e 2; Laje da Churra e Pedra da Costa.

As Breias 1, 5 e 9 ficam a menos de $6 \mathrm{~km}$ para sudoeste do lugar do achado do machado de Bujões/Barcelos da Folgadoura, Vilar de Murteda, em Viana do Castelo (Zbyszewski e Ferreira,1955; Fernandes et alii, 2011). Figueiró 1 e 2 e a Laje da Churra, ficam nas imediações do túmulo da Idade do Bronze Final da Cova da Moura, Carreço (Viana, 1955; Bettencourt, 2013). A $2,7 \mathrm{~km}$ a norte da Laje da Churra, existe, ainda, o povoado do Bronze Final de Santo António (Bettencourt, 2013; Oliveira e Bettencourt, 2020). Nas imediações de ambos os locais há inúmeras pias salineiras cortadas na rocha do litoral cuja emergência tem vindo a ser associada à Idade do Bronze (Bettencourt et alli, 2020; Oliveira e Bettencourt, 2020). Quanto à Pedra da Costa 1 é de referir que fica a poucas centenas de metros para oeste do topo do Monte do Castro, onde terá existido uma ocupação do Bronze Final (Bettencourt, 1988).

Deste modo, observa-se que na área da maioria dos sítios gravados estudados há, efetivamente, vestígios da Idade do Bronze (Figura 8), embora outros estudos sejam necessários para se aferir melhor possíveis inter-relações.

Verificaram-se, também, as inter-relações possíveis entre estes motivos gravados e os recursos mineiros passíveis de terem sido explorados durante a Idade do Bronze, como o estanho, o ouro e a prata, pelo facto de, à ampla escala de análise, Bettencourt (2017a, 2017b) ter considerado que estes motivos ocorrem sobretudo em áreas ricas em estanho. $\mathrm{Na}$ análise efectuada através dos recursos mineiros referidos nas Cartas Geológicas de Portugal, na escala 1/500oo da região (Figura 9), verifica-se que, na bacia do rio Lima, esta inter-relação só é evidente para o núcleo da Breia, embora deva ser salientada a presença de três jazidas de estanho nas imediações do monte de Romarigães, no concelho de Paredes de Coura, a cerca de $5 \mathrm{~km}$ para sudoeste da Pedra da Costa 1. De sublinhar que apesar de não referidas na cartografia geológica, houve exploração de estanho no alto da serra de Santa Luzia, durante o século $\mathrm{XX}$, atividade eventualmente associada à introdução de novas imagéticas durante a Idade do Bronze, patentes na Laje da Churra e em Figueiró 1 e 2.

No curso médio da bacia do rio Lima, o facto de Gião 1 e de Chã da Rapada 3 não aparentarem relação direta com algum recurso mineiro analisado, o que não permite, por agora, extrapolar esta inter-relação para toda a região.

A continuação da investigação sobre este tema possibilitará, de futuro, confirmar ou infirmar algumas das hipóteses aqui equacionadas.

\section{AGRADECIMENTOS}

Este trabalho foi realizado no âmbito do projeto de dissertação de Mestrado de Diogo Marinho, intitulada Círculos segmentados gravados no Noroeste de Portugal que se inscreve no projeto coletivo Artes rupestres das Idades do Bronze e do Ferro do Norte de Portugal: do inventário à interpretação e divulgação, desenvolvido pelos três subscritores deste trabalho.

\section{BIBLIOGRAFIA}

ALVES, Lara Bacelar (2009) - O sentido dos signos. Reflexões e perspetivas para o estudo da arte rupestre do pós-glaciar no norte de Portugal. In BEHRMANN, Balbín, ed. - Arte Rupestre al Aire libre: investigación, protección y diffusion. Castilla y Leon: Consejeria de Cultura da Junta de Castilla y Leon, pp. 381-49o.

ALVES, Lara Bacelar (2012) - Génio e Talento do Passado. A Arte Gravada do Penedo do Encanto e da Chã da Rapada. Viseu: ADERE-PG / Arqueohoje, Lda.

ALVES, Lara Bacelar (2013) - Monte de Góis, Caminha. A Rock Art Sanctuary on the Banks of River Minho. In BETTENCOURT, Ana M. S. ed. - The Prehistory of the Northwestern Portugal, Territórios da Pré-História em Portugal, Vol. 2. Braga and Tomar: CEIPHAR and CICTEM, pp. 169-183.

BAPTISTA, António Martinho (1983/84) - A Arte rupestre do Norte de Portugal: uma perspetiva. Portugália, Nova Séria, 4/5: 71-82, IV ests.

BETTENCOURT, A. M. S. (1988) - O molde de foice de talão do Castro de Álvora, Cadernos de Arqueologia 5: 155-161.

BETTENCOURT, A. M. S. (2013) - O Bronze Final no Noroeste português. Uma rede complexa de lugares, memórias e ações. Estudos Arqueológicos de Oeiras, 20, pp. 157-172. 
BETTENCOURT, A. M. S. (2017a) - Post-palaeolithic rock arts of north-western Portugal; an approach. In BETTENCOURT, Ana M. S.; SANTOS-ESTĖVEZ, Manuel; SAMPAIO, Hugo; CARDOSO, Daniela eds. - Recorded Places, Experienced Places. The Holocene Rock Art of the Iberian Atlantic Northwest, British Archaeological Reports - BAR, Oxford: BAR Publishing, pp. 123-149.

BETTENCOURT, A. M. S. (2017b) - Gravuras rupestres do noroeste português para além das artes atlântica e esquemática. In J. M. Arnaud; A. Martins (eds.), Arqueologia em Portugal - 2017. Estado da Questão, Lisboa: Associação dos Arqueólogos Portugueses, pp. 1039-1053.

BETTENCOURT, A. M. S. (2019a) - Equídeos nos montes do noroeste português. Narrativas míticas gravadas nas rochas. In PEREIRA, Andreia ed. - O Garrano: Contributos da Investigação Histórico-Arqueológica, Antropológica e Equestre para a sua valorização, Viana do Castelo: Câmara Municipal, 135-148.

BETTENCOURT, A. M. S. (2019b) - Artes rupestres do Alto Minho. In CAMPELO, Álvaro, ed. - Património Artístico e Cultural do Alto Minho. Uma Viagem no Tempo. Viana do Castelo: Comunidade Intermunicipal do Alto Minho.

BETTENCOURT, A. M. S.; LUZ, Sara; OLIVEIRA, Nuno; SIMÕES, Pedro; Maria Isabel C.; ABAD-VIDAL, Emilio (2020) - Produção de sal marinho no Noroeste português. Alguns dados para uma reflexão. In Arqueologia em Portugal 2020 / Estado da Questão, Lisboa: Associação dos Arqueólogos Portugueses.

BRADLEY, Richard (1997) - Rock Art and the Prehistory of Atlantic Europe. Signing the Land. London: Routledge.

BRADLEY, R. (2002), - Access, Style and Imagery: The Audience for Prehistoric Rock Art in Atlantic Spain and Portugal, 400o-200o BC. Oxford Journal of Archaeology, 21, pp. 231-247. doi:10.1111/1468-0092.0016o.

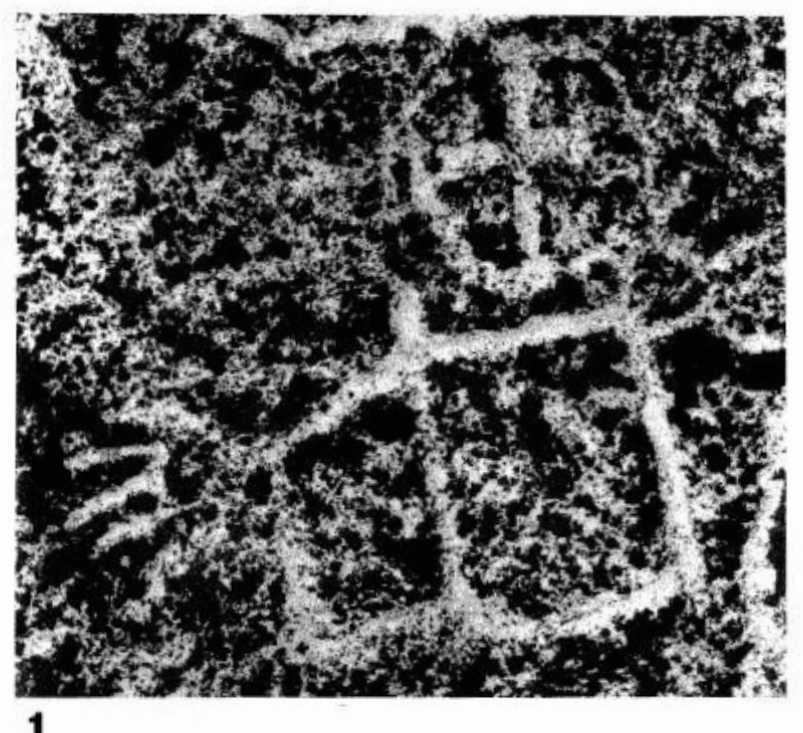

SÁ, Sofia (2015) - turismo arqueológico: um projeto de valorização da arte rupestre no vale do Lima. Braga: Universidade do Minho (Dissertação de Mestrado).

SANTOS, Ana (2014) - A Laje da Churra (Paço, Carreço, Viana do Castelo): estudo monográfico de um lugar gravado. Braga: Universidade do Minho (Dissertação de Mestrado).

VÁZQUEZ VARELA, J. (1983) - Los Petrglifos Gallegos. Zephyrus: Revista de prehistoria y arqueología, ISSN 05147336, № 36, 1983, págs. 43-51

VIANA, A. (1960) - Insculturas Rupestres do Alto Minho (Lanhelas e Carreço, Viana do Castelo Portugal). Boletim de la Comisión de Monumentos Históricos y Artísticos de Orense, 22:1-4, pp. 209-321.

BETTENCOURT, A.M.S E ABAD VIDAL, E. (2014) - Corpus Virtual de Arte Rupestre do Noroeste (www.cvarn.org).

BETTENCOURT, A. M. S.; SANTOS-ESTÉVEZ, M. (2018) - A Geografia Mágica do Monte de São Silvestre através da Arte Rupestre. Braga: Lab2PT.

CARDoso, D.; BETTENCOURT, A. M. S. (2015) - Arte "esquemática" de ar livre na bacia do Ave (Portugal, NO Ibérico): espacialidade, contexto, iconografia e cronologia, Estudos do Quaternário, 13, pp. 32-47.

DINIS, A.; BETTENCOURT, A. M. S. (2009) - A arte atlântica do Crastoeiro (Noroeste de Portugal): contextos e significados, Gallaecia, 28, pp. 41-47.

OLIVEIRA, Nuno; BETTENCOURT, Ana M. S. (2020) O povoado de Santo António (Afife, Viana do Castelo), na Idade do Bronze Final, Antrope, 13, no prelo.

PEÑA SANTOS Antonio de la; VÁZQUEZ VARELA, José Manuel_(1979) - Los petroglifos gallegos: grabados rupestres prehistóricos al aire libre en Galicia. Ediciós do Castro.

PEÑA SANTOS Antonio de la; REY GARCÍA, José Manuel (2001) - Ideología y sociedad en los grabados rupestres galaicos, Quadernos de Prehistòria i Arqueologia de Castelló, 22, pp. 235-265.

Figura 1 - Pormenor da rocha 1 do Gião 1 com representação de círculo segmentado; (Fonte: Baptista 1980, 84, in Sá, 2015). 

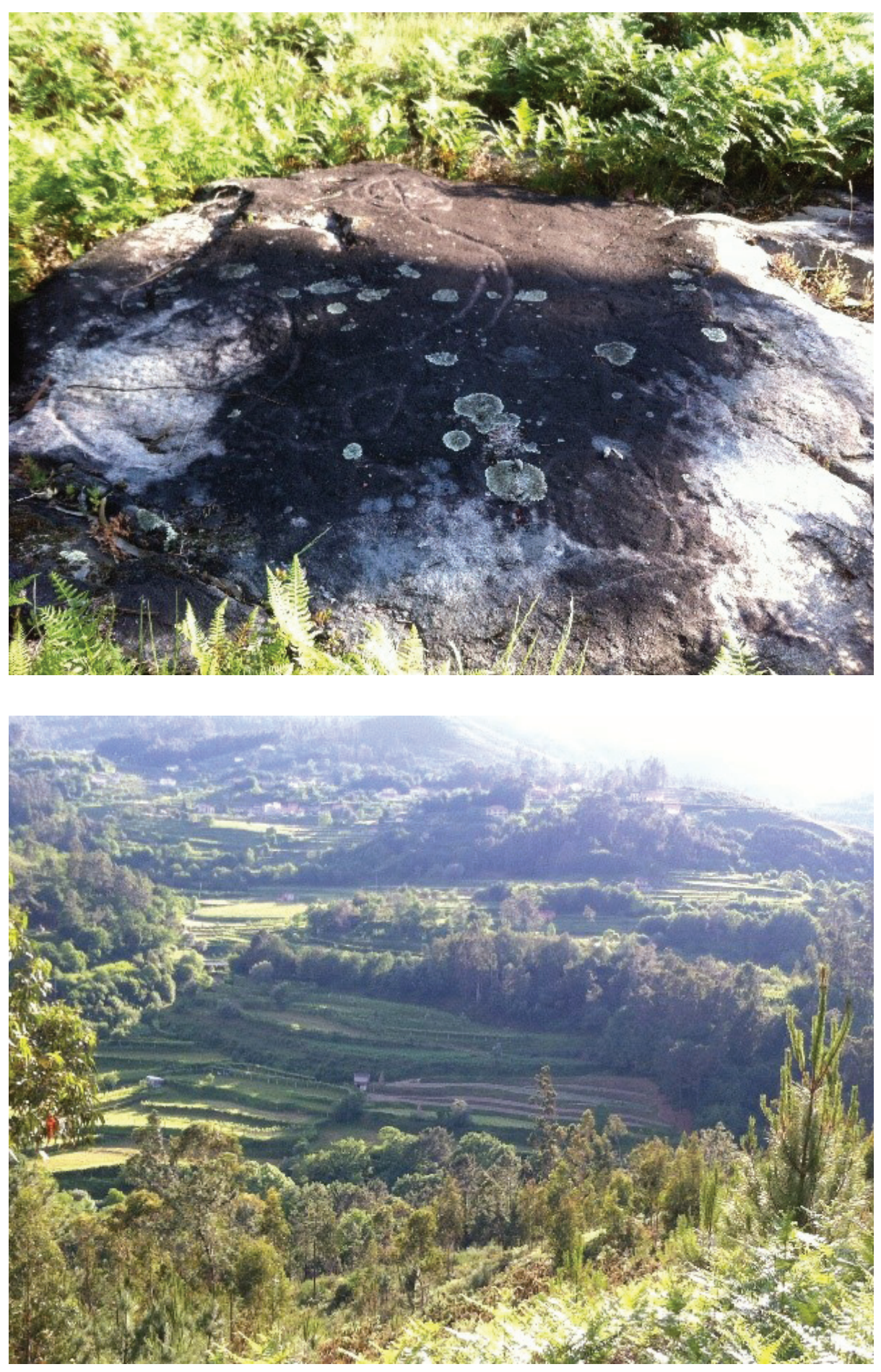

Figura 2 - Círculo segmentado da Pedra da Costa I em último plano (em cima) e Vale da ribeira de Frades (em baixo). (Fonte: Ana M. S. Bettencourt). 


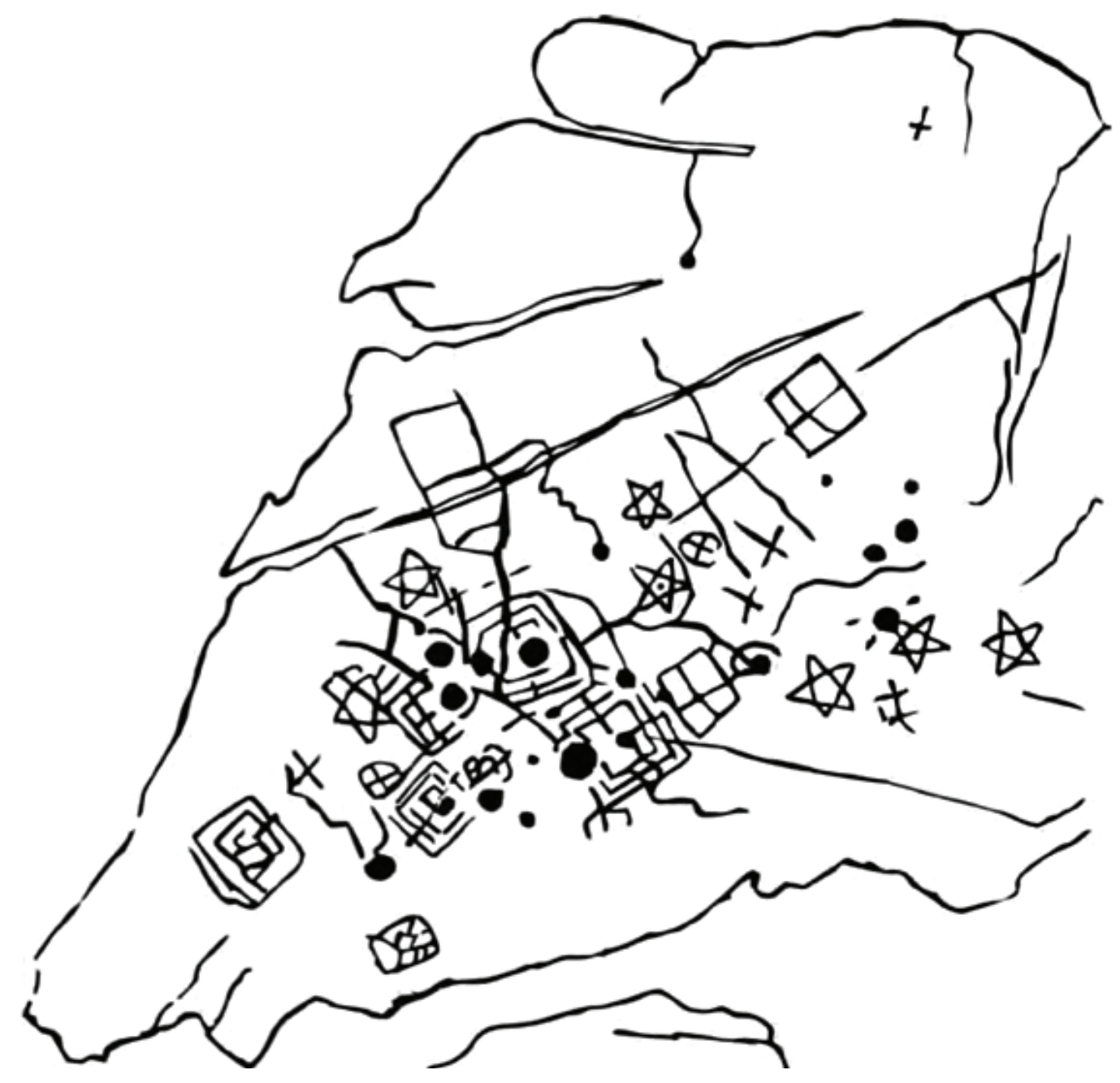

Figura 3 - Chã da Rapada 3. Esquema geral da composição (Fonte: Alves, 2012, p. 21).
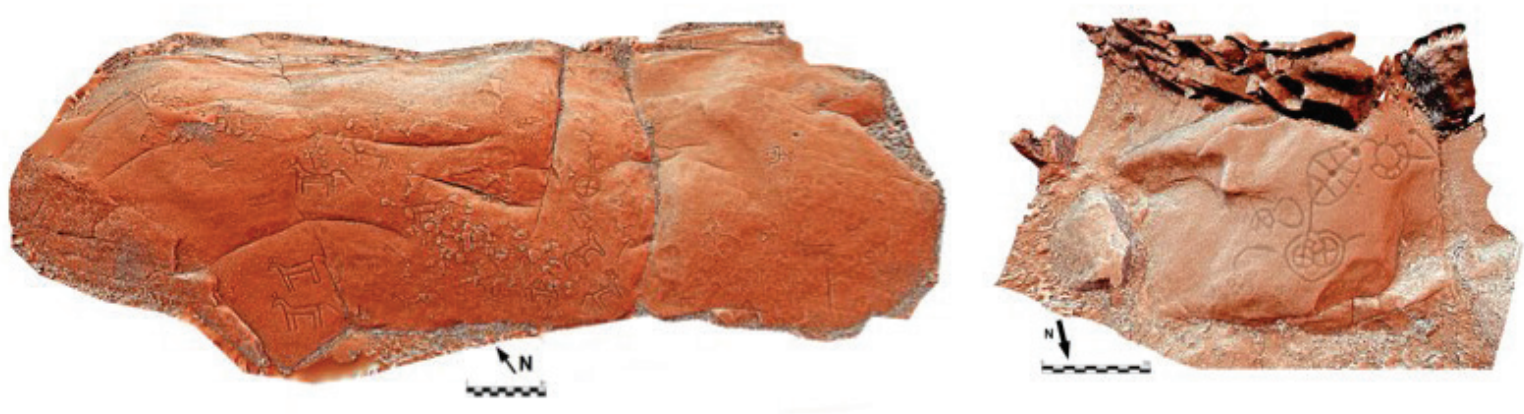

Figura 4 - Fotogrametria das Breias 5 e 9 (Fonte: Bettencourt e Santos-Estévez, 2018, p. 59 e 72 ). 


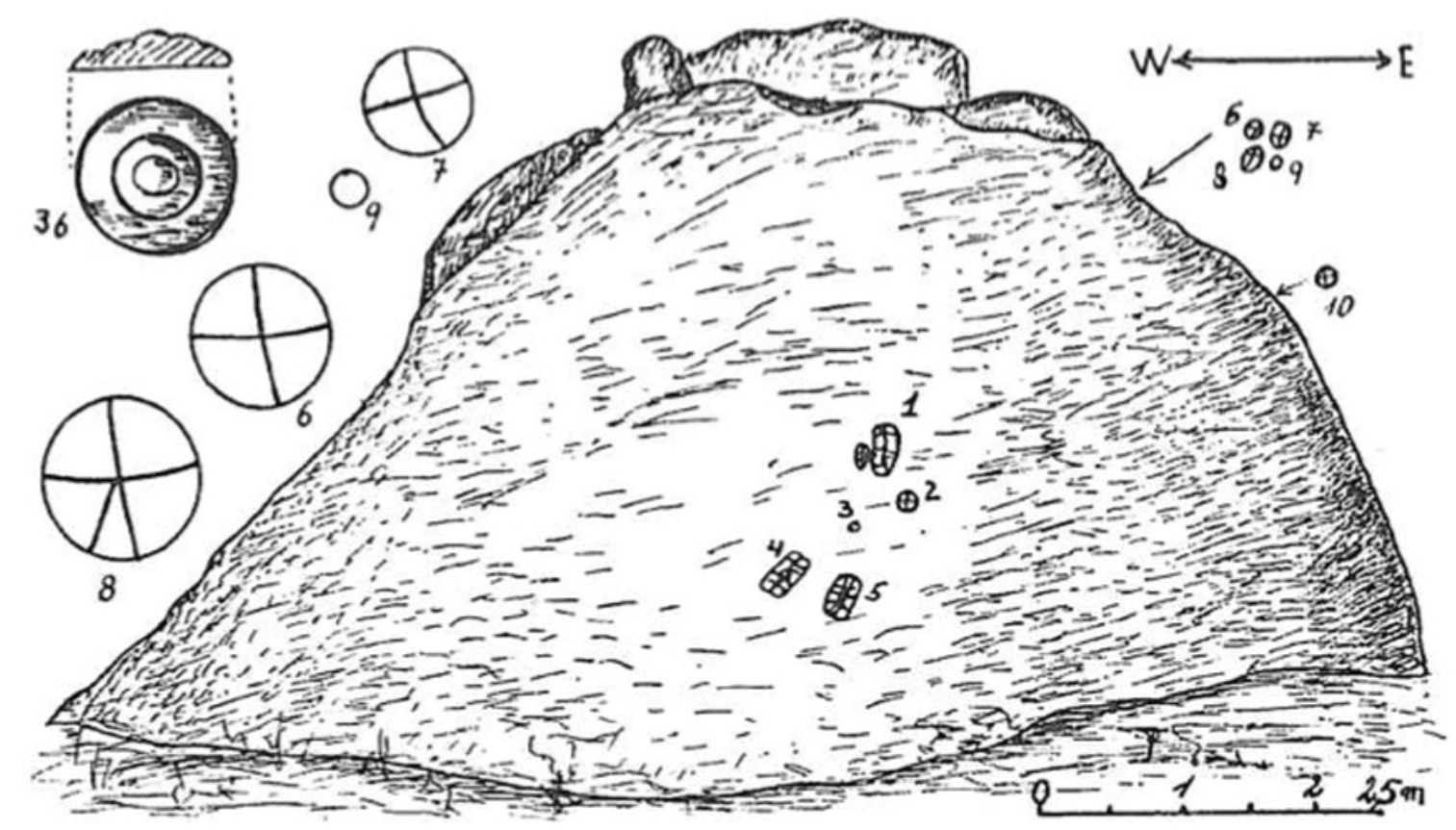

Figura 5 - Figueiró 1 segundo desenho de Viana (1960); (Fonte: Viana. A, 1960).

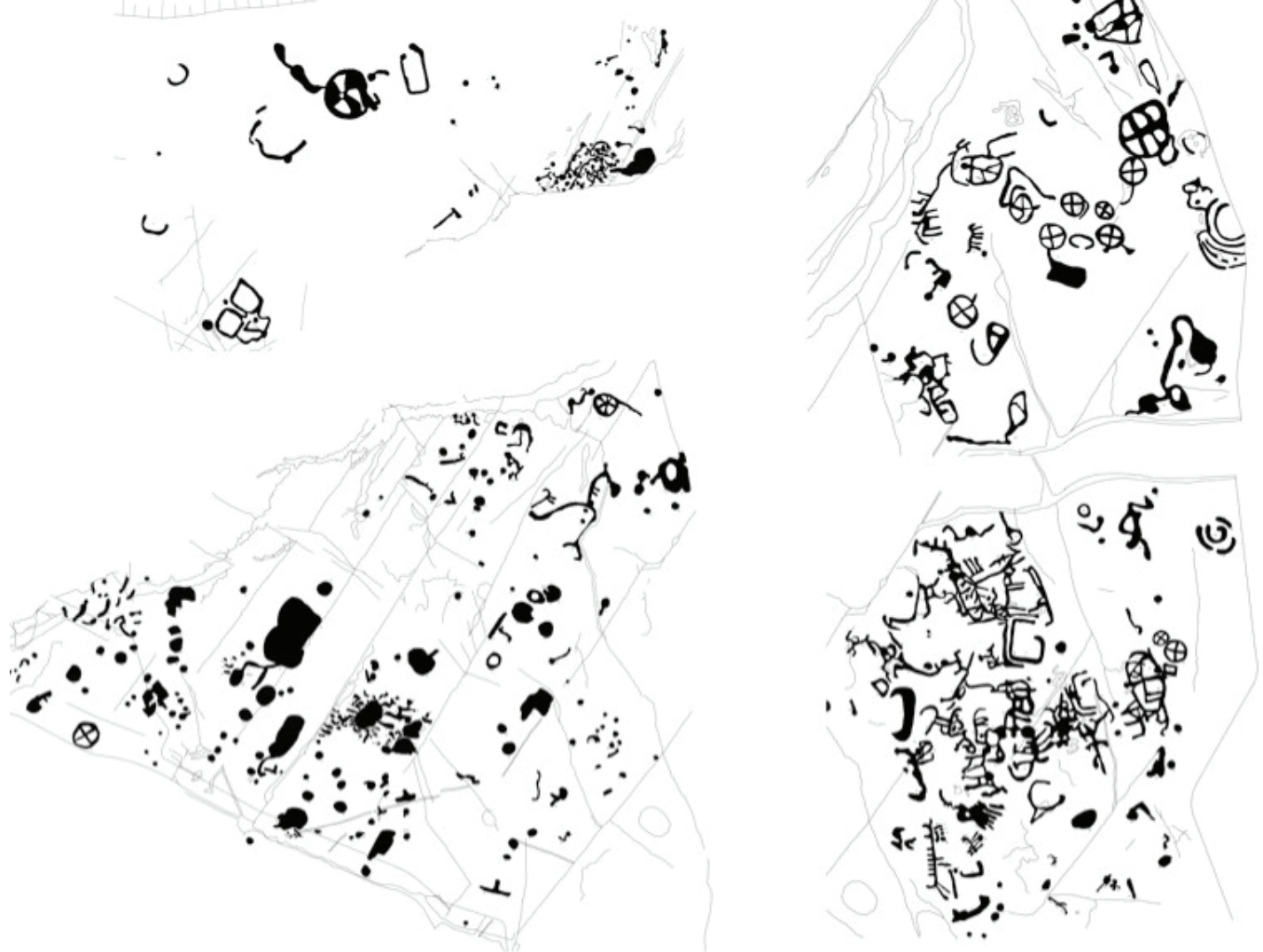

Figura 6 - Painéis 2, 3 (em cima), 5 e 6 (em baixo) da Laje da Churra (Fonte: Santos, 2014, adaptado). 


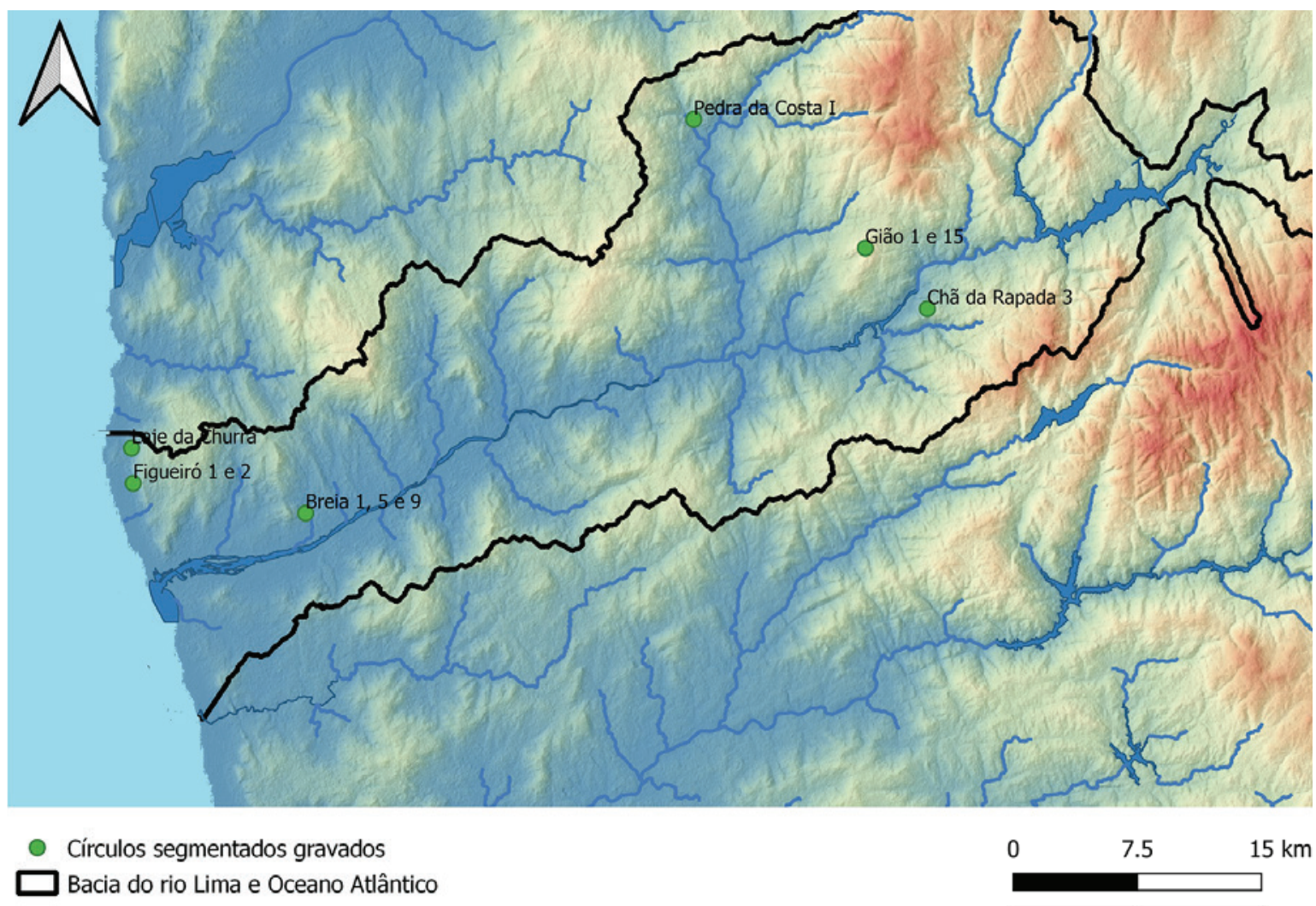

Figura 7 - Distribuição espacial dos círculos segmentados gravados nos cursos médio e inferior do rio Lima.

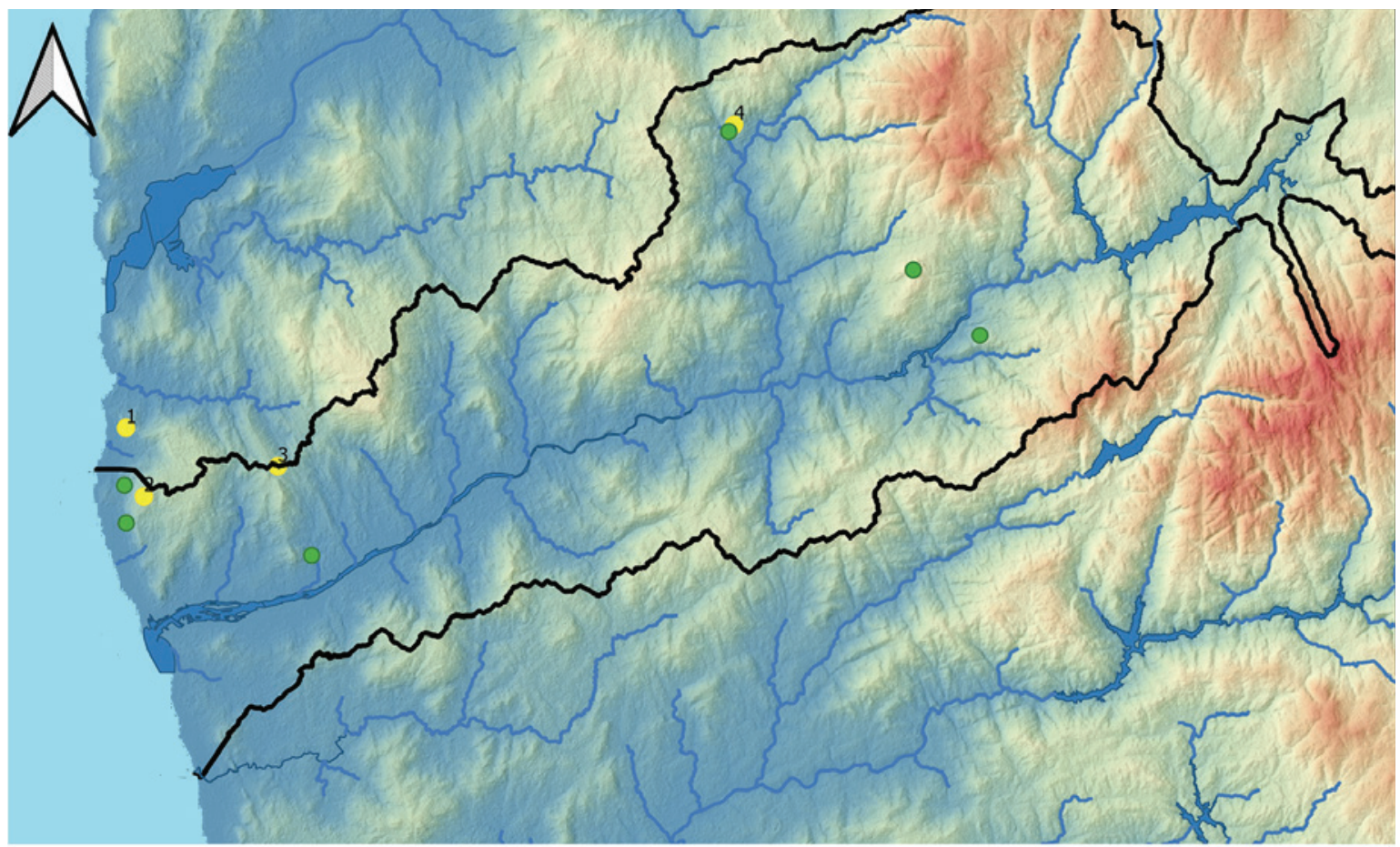

- Círculos segmentados gravados

1 - Povoado Santo António; 2 - Cova da Moura; 3 - Machado do Folgadoiro; 4 - Ocupação do Bronze Final/Monte do Crasto

Bacia do rio Lima e Oceano Atlântico

Figura 8 - Inter-relação dos afloramentos gravados com círculos segmentados e sítios arqueológicos da Idade do Bronze. 


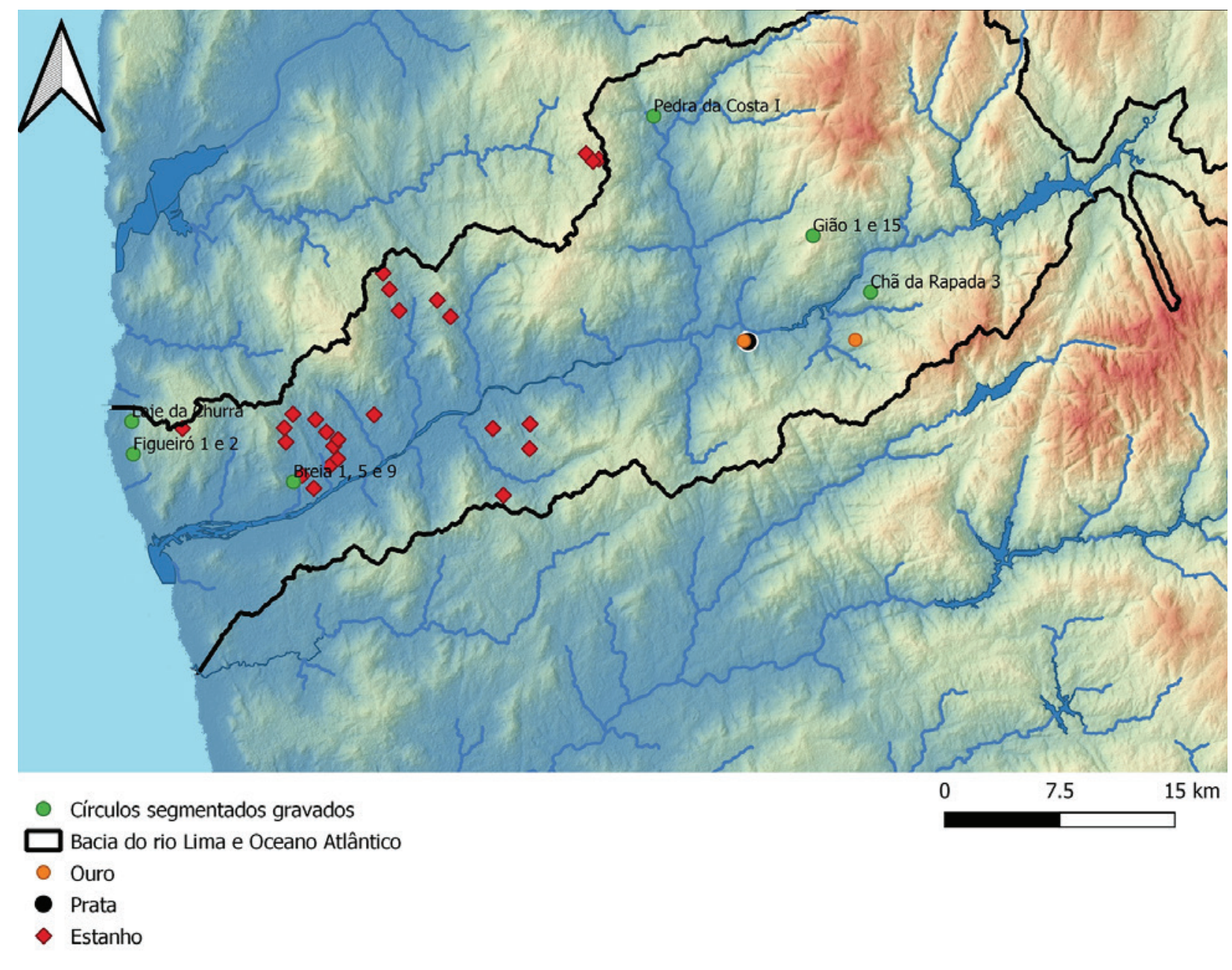

Figura 9 - Inter-relação dos lugares gravados com círculos segmentados e recursos mineiros de estanho, prata e ouro. 


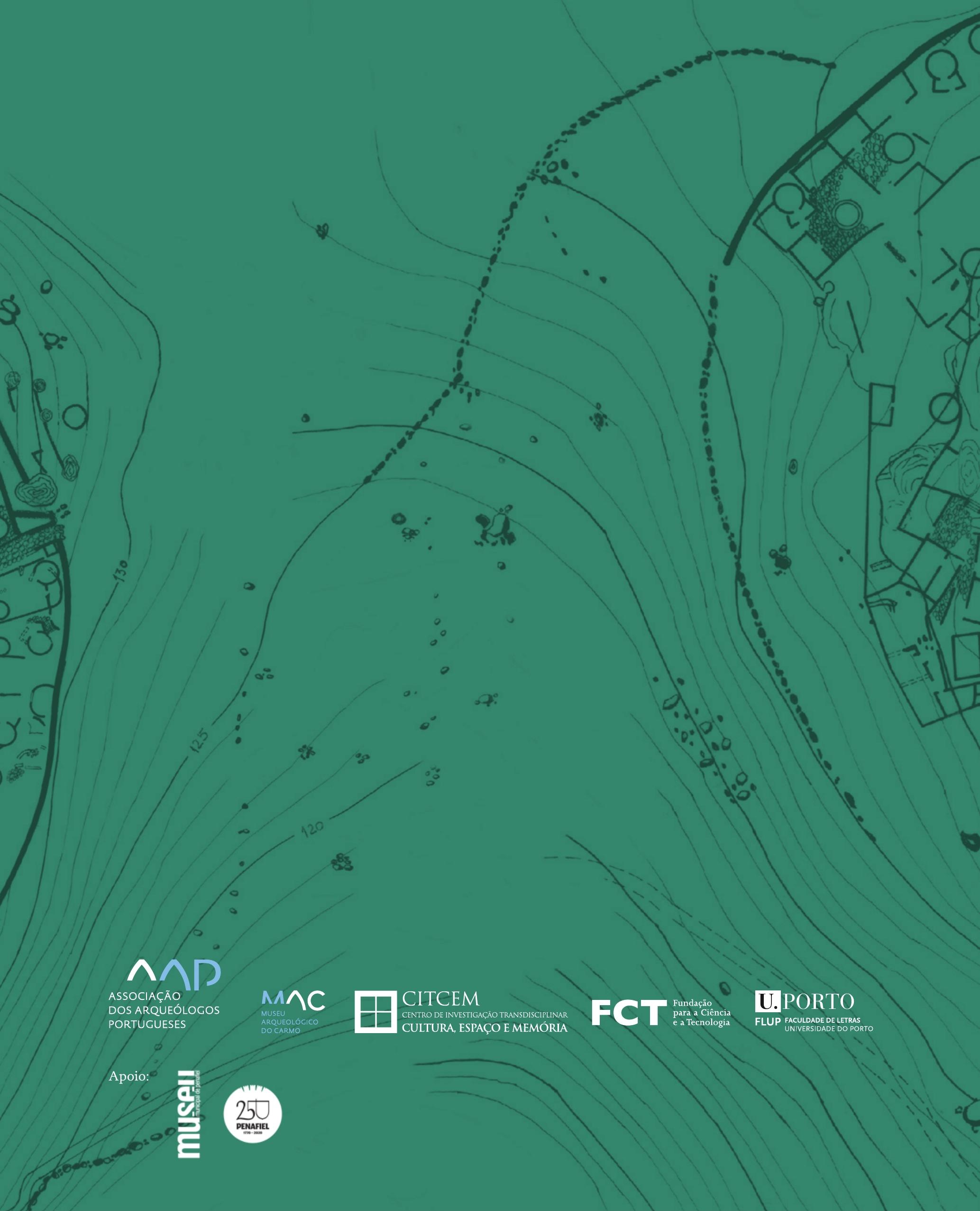

